\title{
Storage Capacity Enhancement and Reservoir Management Using Water Extraction: Four Site Case Studies
}

\author{
Guoxiang Liu, Charles D. Gorecki,* Jordan M. Bremer, Ryan J. Klapperich, and \\ Jason R. Braunberger
}

Energy \& Environmental Research Center, University of North Dakota 15 North 23rd Street, Stop 9018, Grand Forks, ND 58202-9018

\begin{abstract}
Water extraction from carbon dioxide $\left(\mathrm{CO}_{2}\right)$ storage reservoirs may be a method to enhance storage capacity and to actively manage storage reservoirs. Previous investigations into the use of water extraction have utilized homogeneous models to assess the feasibility of this technology. This study addressed water extraction based on four hypothetical $\mathrm{CO}_{2}$ storage sites, which varied with respect to heterogeneous lithology, variable structure, and complex internal geometry. The simulation results showed the increased $\mathrm{CO}_{2}$ storage capacity achieved through the use of water extraction varies greatly based on site conditions, ranging from $4 \%$ to $1300 \%$ in the four cases investigated. In all scenarios, water extraction reduced the maximum reservoir pressures approximately $10 \%$ to $20 \%$ during injection. In most scenarios, $\mathrm{CO}_{2}$ plume movement could also be influenced through the use of water extraction. The last two aspects may be very beneficial for risk management and monitoring, verification, and accounting practices for all of the $\mathrm{CO}_{2}$ storage projects.
\end{abstract}

C 2013 The Authors. Published by Elsevier Ltd.

Keywords: Water Extraction; $\mathrm{CO}_{2}$ Storage; Storage Capacity; Pressure Management; Plume Management; Reservoir Simulation; Risk Assessment

\section{Introduction}

Carbon capture and storage (CCS) is a technology to reduce carbon dioxide $\left(\mathrm{CO}_{2}\right)$ emissions to the atmosphere by storing large quantities of $\mathrm{CO}_{2}$ in deep geologic reservoirs. Several geological options for CCS have been considered, including coal beds (White et al., 2005; Liu and Smirnov, 2007, 2008), depleted oil/gas reservoirs (Shaw and Bachu, 2002; Kovscek, 2002; Flett et al., 2005), and deep saline formations (DSFs) (Bachu and Adams, 2003; Kumar et al., 2005; Holloway et al., 2004; Liu, 2012). DSFs are the largest potential $\mathrm{CO}_{2}$ storage resources and have received increased attention in recent years. According to the Intergovernmental Panel on Climate Change (IPCC) report, the lower estimate of storage capacity in DSFs is $1000 \mathrm{Gt}$ of $\mathrm{CO}_{2}$, which is far greater than estimations for oil and gas fields and unminable coal seams (Metz et al., 2005). Therefore, the utilization of DSFs plays a crucial role in successfully implementing the scale-up of storage from pilot and demonstration projects to commercial operations. Deep saline water extraction from $\mathrm{CO}_{2}$ storage formations has been proposed as one potential method to enhance $\mathrm{CO}_{2}$ storage, manage reservoir pressure, and alter $\mathrm{CO}_{2}$ plume movement (Buscheck et al., 2010; Celia and Bachu, 2003; Hosseini and Nicot, 2012; Eke et al., 2011; Burtin and Bryant, 2009, IEA Greenhouse Gas R\&D Programme, 2009, 2014; Saini et al., 2013; Gorecki et al., 2013).

Most publications have demonstrated the basic concept of water extraction from a $\mathrm{CO}_{2}$ storage

* Corresponding author. Tel.: +1-701-777-5355; fax: +1-701-777-5181.

E-Mail Address: cgorecki@undeerc.org. 
reservoir based on reservoir simulations of idealized geologic models (Buscheck et al., 2010; Hosseini and Nicot, 2012; Eke et al., 2011; Burtin and Bryant, 2009). For example, Buscheck et al. (2010) modeled the effects of water extraction on $\mathrm{CO}_{2}$ storage by comparing the results with and without water extraction to an idealized system. Their conclusions indicate that water extraction may be effective for $\mathrm{CO}_{2}$ plume manipulation and reduction of pressure buildup based on an assumed 1 to 1 ratio of water extraction to $\mathrm{CO}_{2}$ injection (Buscheck et al., 2010). In addition, the thermal footprint area, thermal drawdown, and cumulative $\mathrm{CO}_{2}$ storage were investigated based on 5-, 12-, and 16-well patterns over various time periods and well spacings for $\mathrm{CO}_{2}$ injection and water production (Buscheck et al., 2010). Hosseini and Nicot (2012) developed an analytical system to test the injectivity impacts and pressure reduction gains through brine extraction from $\mathrm{CO}_{2}$ storage reservoirs and reinjection into shallower reservoirs based on a generic model. Most of the studies do not include any heterogeneity effects or reflect real field structures or conditions, nor do they aim to optimize strategies related to injection and extraction. Therefore, more questions related to the capacity and injectivity of DSFs, especially pressure behavior, $\mathrm{CO}_{2}$ plume movement, and extraction rates, remain. Additional research is needed that takes into account the real/potential $\mathrm{CO}_{2}$ storage site structure and geologic properties with various optimization scenarios for injection and production wells (IEA Greenhouse Gas R\&D Programme, 2012), ultimately estimating $\mathrm{CO}_{2}$ storage capacity dynamically with consideration of injectivity and reservoir pressure interference through the use of reservoir simulation. As a result, this study was undertaken to investigate 1) how much $\mathrm{CO}_{2}$ storage capacity can be increased by implementing water extraction; 2) how reservoir pressure buildup varies under different reservoir conditions, including geologic heterogeneity structures, and fluid properties; 3) the effects on the $\mathrm{CO}_{2}$ plume movement with water extraction; and 4) how injection and extraction scenarios can be optimized (IEA Greenhouse Gas R\&D Programme, 2012; Liu et al., 2012; Klapperich et al., 2012; Saini et al., 2013).

In this study, four $\mathrm{CO}_{2}$ storage sites were selected: the Ketzin project site in Germany, the Zama oil field in Canada, the Gorgon project site in Australia, and the Teapot Dome oil field in the United States, as shown in Fig. 1 (IEA Greenhouse Gas R\&D Programme, 2012). These sites represent offshore and onshore cases with pilot- and commercial-scale plans and differing formation water qualities, injectivities, climates, and beneficial water use opportunities. The following describes the methods employed, case studies by site, and conclusions for the entire investigation.

\section{Method}

To achieve the goal of understanding reservoir dynamics for $\mathrm{CO}_{2}$ storage with water extraction, four "idealized" real-world storage sites were selected and modeled. Selected sites were chosen to represent a range of reservoir types that could be used for commercial-scale $\mathrm{CO}_{2}$ storage targets. Another goal of the study, not discussed in this paper, was to assess the utility of extracted water as a resource at these sites. Therefore, factors such as regional climate and water quality were also taken into consideration when 


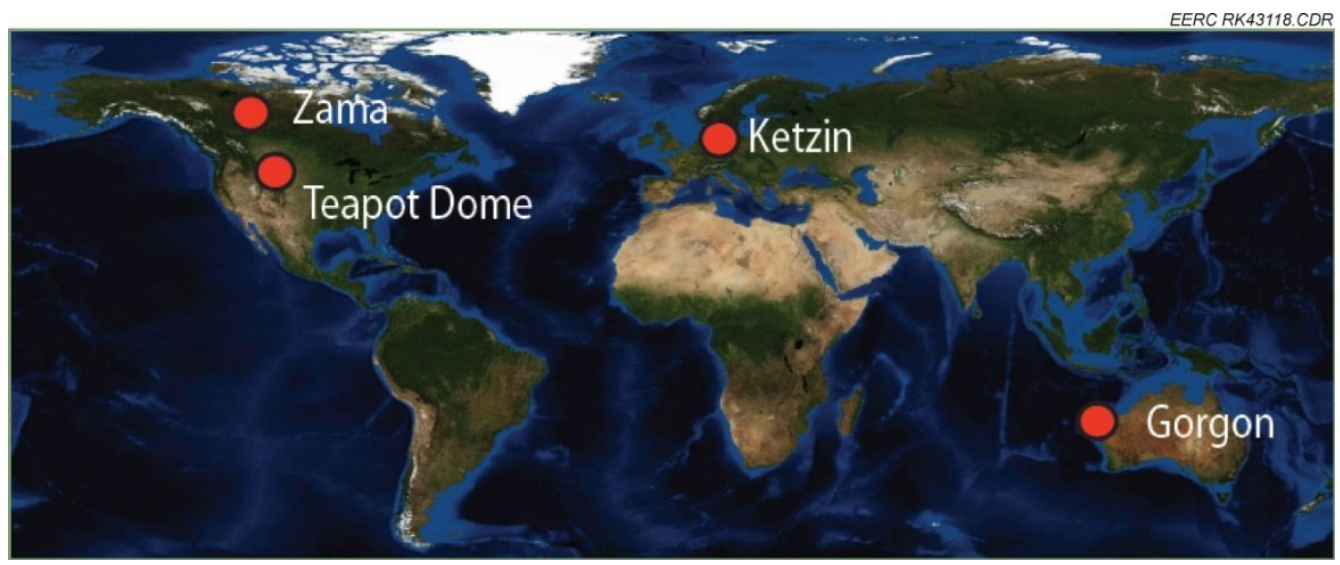

Fig. 1. Map depicting the location of the selected sites.

identifying possible sites. The selected sites represent a range of geologic and geophysical conditions as well as variations in their climates and regional water demands. The quality of the reservoir water also varied substantially among the four sites. These properties are summarized in Table 1 .

Geologically, the sites represent both traditional clastic reservoir environments (Ketzin, Teapot Dome, and Gorgon) and carbonate reservoir systems (Zama). Structurally speaking, domes (Ketzin and Teapot Dome), anticlines (Gorgon), and reef structures (Zama) are represented by the sites. Water quality ranged from nearly fresh at Teapot Dome to concentrated brine $(>180,000)$ at Zama and Ketzin. Additional variability was achieved in terms of climate and regional water stress. Sites ranged in climate from arid (Gorgon) to temperate (Ketzin), with regional water supply ranging from high regional water stress (Teapot Dome and Gorgan) to low regional water stress (Ketzin).

Table 1. Overview of selected case study site characteristics that exhibit ranges of geologic, hydraulic, and surface environment characteristics.

\begin{tabular}{lcccc}
\hline & Ketzin & Gorgon & Teapot Dome & Zama \\
\hline Location & $\begin{array}{c}\text { Central } \\
\text { Germany }\end{array}$ & $\begin{array}{c}\text { Offshore western } \\
\text { Australia }\end{array}$ & Wyoming, western USA & $\begin{array}{c}\text { Northern Alberta, } \\
\text { Canada }\end{array}$ \\
& & & & \\
Depositional Environment & Fluvial & Clastic slope & Mixed; nearshore \\
marine, eolian, deltaic & Carbonate reef \\
Geologic Structure & & & Dome & Pinnacle reef \\
Porosity, $\%$ & Dome & Plunging anticline & $3-17$ & $3-17$ \\
Permeablity, mD & $7-51$ & $0-31$ & $1-591$ & $0.001-2127$ \\
Open/Closed System & $0.03-3400$ & $0-272$ & Open & Closed \\
Reservoir Salinity, TDS, & Open & Open & 9500 & $>180,000$ \\
ppm & $>200,000$ & $7,000-28,000$ & Semiarid & Semiarid \\
Climate & Temperate & Arid & High & Moderate \\
Regional Water Stress & Low & High & & \\
\hline
\end{tabular}


In addition to testing various behaviors of injected $\mathrm{CO}_{2}$ in heterogeneous reservoirs within structures in response to injection and extraction designs, different sites enabled specific testing of other operational aspects. Specifically;

- For the Ketzin Model we tested open vs. closed boundary conditions and the effect of adding more injection and production wells.

- The Zama Model tested injection and production rates from a small, closed structure in order to maximize storage.

- The Gorgon model tested injection and production rates for a reservoir with very large capacity, and how water extraction behaves when pressure maintenance is not necessary, and also how the reservoir behaves under a much larger injection.

- The Teapot Dome Model tested different combinations of injectors and producers, and also the use of horizontal wells.

$\mathrm{CO}_{2}$ storage capacity estimates in this study are based on a dynamic evaluation that takes into account geologic heterogeneity, reservoir pressure interference, well configuration, injectivity/productivity, and boundary condition. The effect of water extraction on dynamic storage capacity was investigated by adding and varying number of water extraction wells and $\mathrm{CO}_{2}$ injection wells. This is typically accomplished by constructing geocellular models of the injection volume and running numerical simulations. The pressure and $\mathrm{CO}_{2}$ plume movement are estimated based on the simulation results.

3-D geocellular models were developed for each study site and populated with data related to porosity, permeability, structure, lithology, formation water quality, temperature, and pressure by using a deterministic model populated with geostatistically simulated data to produce one realization per site representing the $\mathrm{P}_{50}$ case (Schlumberger, 2012). Heterogeneities of these sites were assigned according to variogram ranges attributed to depositional environments from GSLIB (Deutsch and Journel, 1998). The lack of input data did not provide enough variation to create multiple realizations without performing detailed petrophysical analysis, which was beyond the scope of this work. Multiple realizations were attempted, however, by only changing the seed number on the geostatistical property simulation. These results did not provide significant change in the geologic model, and results were near identical when ranked in an attempt to reduce geologic uncertainty. The Ketzin and Gorgon sites were modeled following published methodologies for the two sites, which included a combination of object modeling and truncated Gaussian simulation processes (Court et al., 2010; Klapperich et al., 2013; Fleury et al., 2010; Schilling et al., 2009; CO2CRC Technologies Pty Ltd, 2008, 2009). Teapot Dome utilized over 1200 well tops from the field which were used to identify and model the structure of different horizons. The Zama Field pinnacle reefs contain complex internal geometry and variable structure. These systems were modeled using a combination of object modeling and multipoint statistics using an interpreted reef structural diagram as a training image. The facies model was populated with site-specific heterogeneity and properties developed through Plains $\mathrm{CO}_{2}$ Reduction (PCOR) Partnership characterization activities. It is important to note that two of the selected sites (Zama and Teapot Dome) are depleted oil and gas reservoirs and, as such, are likely to contain varying concentrations of hydrocarbons, which may increase overall treatment costs and/or limit the potential for beneficial use. However, the authors have chosen to use these sites as analogs for similar saline formations in lieu of adequately described formations for the purposes of storage capacity calculations by water extraction.

A compositional reservoir simulator was used for all dynamic modeling and simulations (Computer Modelling Group, 2014a). All scenarios/simulations were run under isothermal conditions with negligible geomechanical behaviors, limited by the maximum cap rock pressure for cap rocks of each respective site. All of the geologic information and modeling parameters, including residual saturations, capillary pressure, relative permeability curves, boundary conditions, and initial reservoir pressure for each site, were derived from published material. If specific data elements were not available from publications, the 
parameters were referenced from similar reservoir types within the Average Global Database (IEA Greenhouse Gas R\&D Programme, 2009).

Evaluation of fluids and flow was limited to formation water, $\mathrm{CO}_{2}$, and various compositions of $\mathrm{CO}_{2}$ dissolved in the formation water. The properties of fluids in models for the four sites were generated by the phase behaviour and fluid property program (Computer Modelling Group, 2014b). The basic pressures and temperatures used in the phase property program were the average values of the specific site. The solubility coefficients were determined and correlated based on the Li-Nghiem Method ( $\mathrm{Li}$ and Nghiem, 1986). The fluid density and viscosity were correlated by the Rowe-Chou aqueous density correlation (Rowe and Chou, 1970) and Kestin aqueous viscosity correlation (Kestin and Shankland, 1984), respectively, for various pressures and temperatures along with depth of the models.

All of the wells in the models were tied to existing wells whenever possible, including the injection well for the Ketzin site in Germany (Kempka and others, 2010; Martens and others, 2011; Wiese, 2010a), the Zama field in Canada (Burke, 2009), and all proposed injection and production wells in the Gorgon site in Australia (Flett and others, 2008, 2009; CO2CRC Technology Pty Ltd, 2008). If additional wells were required for a given scenario, their locations were suggested based on the hydraulic conductivity and geologic structure of the specific site. Well parameters such as perforation interval, radius, and skin were also referenced to published data whenever possible. If such data were not available, the typical values of the well radius of $0.108 \mathrm{~m}$ and a skin of 0 were used for the simulations. Injection wells were perforated in the reservoir interval, while extraction wells were only perforated in the bottom half of the reservoir interval.

For $\mathrm{CO}_{2}$ injection, a commercial-scale injection rate and period were assumed; that is, 1-million tonne/year injection rate ( 2 million tonnes or more in the Gorgon and Ketzin study sites based on injectivities), with a 25-year injection period to meet the maximum $\mathrm{CO}_{2}$ storage and moderate water extraction period. The injection well was controlled by the injection rate and maximum bottomhole pressure (BHP) for all scenarios. If the pressure buildup was less than the maximum BHP constraint, the specified injection rate was used. Otherwise, the injection rate was reduced to match the maximum BHP constraint. The maximum BHP for the specific site was determined by the static pressure at the depth of the well bottomhole with an extra $10 \%$ buffer.

Water extraction was carried out based on the minimum BHP and maximum production rate. The reasonable minimum BHP used for most of the scenarios was set based on the specific case study by referring to production operating history and site characterization to avoid any mechanical issues. Water extraction was shut in at each extraction well at the end of the injection period or when $\mathrm{CO}_{2}$ breakthrough occurred (>1000 $\mathrm{m}^{3} /$ day).

All simulation scenarios were developed to compare the effects of different injection and extraction scenarios under several geologic conditions in an attempt to improve $\mathrm{CO}_{2}$ storage capacity and manage the storage reservoirs. In addition, $\mathrm{CO}_{2}$ plume and pressure management strategies were investigated to analyze the potential decrease in risk by controlling the $\mathrm{CO}_{2}$ plume and decreasing reservoir pressure associated with $\mathrm{CO}_{2}$ storage (IEA Greenhouse Gas R\&D Programme, 2012; Liu et al., 2012; Klapperich et al., 2012). More detailed results for the entire study can be found in the published report (IEA Greenhouse Gas R\&D Programme, 2012).

\section{Case Studies}

\subsection{Ketzin Case Study}

\subsubsection{Site Characterization}

The Ketzin pilot site, led by the GFZ German Research Centre for Geosciences, is Europe's longest- 
operating onshore $\mathrm{CO}_{2}$ storage site, with the aim of increasing the understanding of geologic storage of $\mathrm{CO}_{2}$ in saline formations. Located near Berlin, the Ketzin pilot site has been in operation since 2004 and comprises three wells to depths of 750 to $800 \mathrm{~m}$ and one shallow observation well. Since June 30, 2008, $\mathrm{CO}_{2}$ has been injected into a 630- to 650-m-deep sandstone unit on an anticlinal structure in the Northeast German Basin. After 44 months of injection (February 2012), about 59,000 tonnes of $\mathrm{CO}_{2}$ has been stored successfully. However, the Ketzin project was completed in December 2013.

Ketzin lies on top of the Ketzin-Roskow Anticline, a double plunging structure trending northeastsouthwest, approximately $12 \times 43 \mathrm{~km}$ in size, with a maximum vertical closure of approximately $300 \mathrm{~m}$. The reservoir unit for the site is the Stuttgart Formation, which consists of a series of fluvial channels surrounded by low-reservoir-quality floodplain deposits, shown in Fig. 2 (left) (Norden et al., 2010). The site is relatively shallow, with the reservoir unit being approximately $650 \mathrm{~m}$ deep. Several separate modeling efforts have been produced over the course of the project that served as templates, parameters, and data sources for model production (Flett et al., 2009; Forster et al., 2006; Prevedel et al., 2008; Frykman et al., 2006).

The Ketzin simulation results presented in this paper are a theoretical case study and do not reflect the real site operational conditions (this pilot site is a research and development project and limited by legal regulations to a maximum amount of stored $\mathrm{CO}_{2}$ of $<100,000$ tonnes).
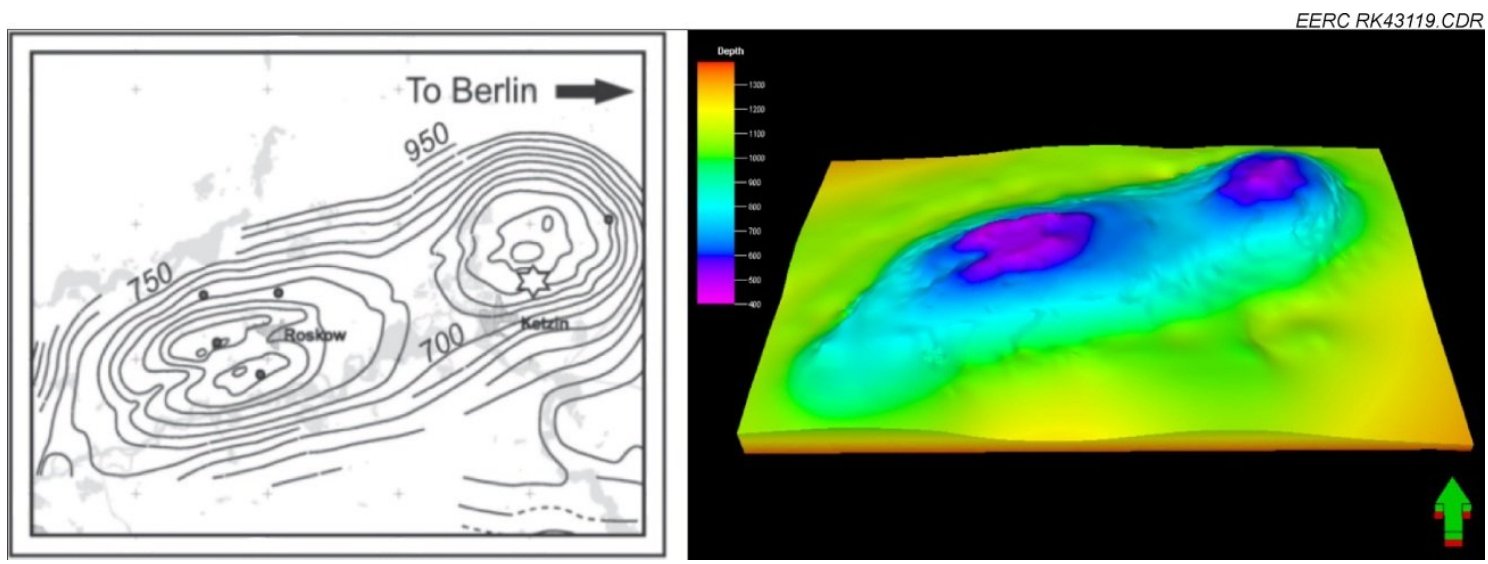

Fig. 2. Stuttgart Formation structural map (left [Norden et al., 2010]) and modeled surface produced from the data (right).

\subsubsection{Modeling}

Locations, wireline logs, and Stuttgart Formation structure maps were incorporated for the injection and monitoring wells according to data presented in Norden et al. (2010). Additionally, fluvial analog data collected for the Stuttgart Formation's fluvial system input parameters were integrated into the channel shape and facies-modeling process (Kempka et al., 2010). Most of the properties and parameters for the modeling and simulations, initial reservoir pressure, and well designs were based on publications of the Ketzin project by the GFZ German Research Centre and associated research projects (Court et al., 2010; Frykman et al., 2006; Kopp et al., 2006; Forster et al., 2006; Henninges et al., 2011; Martens et al., 2010; Wiese et al., 2010a, b; Würdemann et al., 2010). The model dimension used in this study was $29,317 \times 51,370 \times 915 \mathrm{~m}$, which extended the model from $5000 \times 5000 \times 400 \mathrm{~m}$, as reported by Kempka et al. (2010), to fit a commercial-sized injection without experiencing model edge effects (Fig. 2 [right]). Detailed properties are listed in Table 2. 
Table 2. Ketzin Model Properties

\begin{tabular}{lll}
\hline Property & Value & Source \\
\hline Total Porosity & $7 \%-51 \%$, avg: $24 \%$ & Norden et al., 2010 \\
Effective Porosity & $0 \%-50 \%$, avg: $12 \%$ & Norden et al., 2010 \\
Permeability & $0.03-3400 \mathrm{mD}$, avg: $232 \mathrm{mD}$ & Norden et al., 2010 \\
Thickness & $80 \mathrm{~m}$ & Würdemann et al., 2010 \\
Depth & $\sim 650 \mathrm{~m}$ & Würdemann et al., 2010 \\
Pressure, average & $9623.7 \mathrm{kPa}$ & Würdemann et al., 2010 \\
Temperature, average & $38^{\circ} \mathrm{C}$ & Prevedel et al., 2008 \\
Average $\mathrm{CO}_{2}$ Density & $643.91 \mathrm{~kg} / \mathrm{m}^{3}$ & Massachusetts Institute of Technology, 2011 \\
Variogram Range, long & 398 & IEA Greenhouse Gas R\&D Programme, 2009 \\
Variogram Range, short & 108 & IEA Greenhouse Gas R\&D Programme, 2009 \\
Total Dissolved Solids (TDS) & $228.8-236.5 \mathrm{~g} / \mathrm{L}$ & Würdemann et al., 2010 \\
Channel Orientation & $15^{\circ}-20^{\circ}$ & Forster et al., 2006 \\
Sinuosity Amplitude & $100-250 \mathrm{~m}$ & Forster et al., 2006 \\
Wavelength & $5000-9000 \mathrm{~m}$ & Forster et al., 2006 \\
Belt Width & $100-1600 \mathrm{~m}$ & Forster et al., 2006 \\
Channel Thickness & $1-8 \mathrm{~m}$ & Forster et al., 2006 \\
\hline
\end{tabular}

${ }^{1}$ Modeled reservoir pressure ranges from 4646 to $13,460 \mathrm{kPa}$.

$220{ }^{2}$ Water chemistry is the variation in four time-lapse samples, not absolute range.

\subsubsection{Key Results}

A total of 12 cases (Table 3) were designed to analyze different scenarios of injection and water extraction in order to assess differences in storage capacity and efficiency while defining potential volumes of produced water for treatment or disposal. The cases were compared based on how water extraction influences storage capacity and reservoir management through adding extraction wells, varying the number of injection/extraction wells, and converting the same number of injection wells to extraction wells. An injection program was selected that maximized injectivity and, ultimately, storage capacity for an injection of 2 megatonnes a year as a well constraint over a period of 25 years per single vertical injection well. The results of injected $\mathrm{CO}_{2}$ and extracted water for all cases are plotted in Fig. 3 and indicate that the boundary conditions have significant effects on the storage capacity and pressure buildup, especially the case with closed boundaries. The effects between semiclosed (Case 2) and open conditions (Case 3) show less pressure buildup than the case with closed boundaries (Case 1), especially after adding water extraction in Cases 4 and 5. This is due to the strong influence of the dome structure that restricts the $\mathrm{CO}_{2}$ movement laterally. For similar reasons, the storage capacity using two $\mathrm{CO}_{2}$ injectors (Case 6) is better than one $\mathrm{CO}_{2}$ injector and one water extractor in Case 5. In Case 4, which added one extraction well, the storage capacity was increased $98 \%$ to $25.7 \mathrm{Mt}$ from $13.0 \mathrm{Mt}$ in Case 2 with only one injection well. This is an example that water extraction could enhance the $\mathrm{CO}_{2}$ storage in the reservoir.

For the multiple extraction well patterns in Cases 7 through 12, the storage capacity increases with additional extraction wells. The percentage increase of $\mathrm{CO}_{2}$ storage with extraction wells is much larger than the cases where the same number of injection wells was utilized. It is likely that in these scenarios, with the utilized well spacing, the pressure interference of injection becomes the dominant factor.

The use of extraction wells assists in reducing the overall reservoir pressure. As an example, Fig. 4 shows that the reservoir pressure reductions are approximately $12 \%$ in the central area of the injection plume as a result of water extraction in Case 4 by comparing the results in Case 2 without water extraction. Along with a pressure reduction, the plume area increased by $32 \%$ as $\mathrm{CO}_{2}$ was drawn south toward the downdip extraction well, as shown in Fig. 5. The reason is that approximately $98 \%$ more $\mathrm{CO}_{2}$ storage space was created by water extraction. Similar results of structurally dominated migration were 
249 observed in Case 5, where open model boundary conditions allowed for a greater injection rate (IEA 250 Greenhouse Gas R\&D Programme, 2012; Liu et al., 2013).

251 Table 3. Case Scenarios and Resulting Storage Capacities for the Ketzin Site

\begin{tabular}{|c|c|c|c|c|c|}
\hline Scenario & $\begin{array}{l}\text { Well Con- } \\
\text { figuration }\end{array}$ & $\begin{array}{l}\text { Averaged Actual } \\
\text { Gas Injection, }{ }^{1} \\
\mathrm{~kg} /(\text { day*well })\end{array}$ & $\begin{array}{l}\text { Water Production, } \\
\mathrm{kg} /(\text { day*well })\end{array}$ & $\begin{array}{l}\text { Boundary } \\
\text { Conditions }\end{array}$ & $\begin{array}{l}\text { Storage } \\
\text { Capacity, Mt }\end{array}$ \\
\hline Case 1 & 1 injector & 451,000 & $\mathrm{NA}^{2}$ & Closed & 4.12 \\
\hline Case 2 (base case) & 1 injector & $1,430,000$ & NA & Semiclosed & 13.0 \\
\hline Case 3 & 1 injector & $1,980,000$ & NA & Open & 18.1 \\
\hline Case 4 & $\begin{array}{l}1 \text { injector } \\
1 \text { extractor }\end{array}$ & $2,810,000$ & 12,752 & Semiclosed & 25.7 \\
\hline Case 5 & $\begin{array}{l}1 \text { injector } \\
1 \text { extractor }\end{array}$ & $3,000,000$ & 13,580 & Open & 27.4 \\
\hline Case 6 & 2 injectors & $3,550,000$ & NA & Semiclosed & 32.4 \\
\hline Case 7 & 4 injectors & $6,954,760$ & NA & Semiclosed & 63.3 \\
\hline Case 8 & $\begin{array}{l}4 \text { injectors } \\
4 \text { extractors }\end{array}$ & $7,170,000$ & 12,700 & Semiclosed & 65.4 \\
\hline Case 9 & 8 injectors & $9,500,000$ & NA & Semiclosed & 86.7 \\
\hline Case 10 & 12 injectors & $14,500,000$ & NA & Semiclosed & 132.0 \\
\hline Case 11 & $\begin{array}{l}12 \text { injectors } \\
13 \text { extractors }\end{array}$ & $24,877,000$ & 65,753 & Semiclosed & 226.7 \\
\hline Case 12 & 25 injectors & $20,100,000$ & NA & Semiclosed & 183.8 \\
\hline
\end{tabular}

${ }^{1}$ Standard conditions $\left(15.5^{\circ} \mathrm{C}, 101.25 \mathrm{kPa}\right)$.

${ }^{2}$ Not applicable.

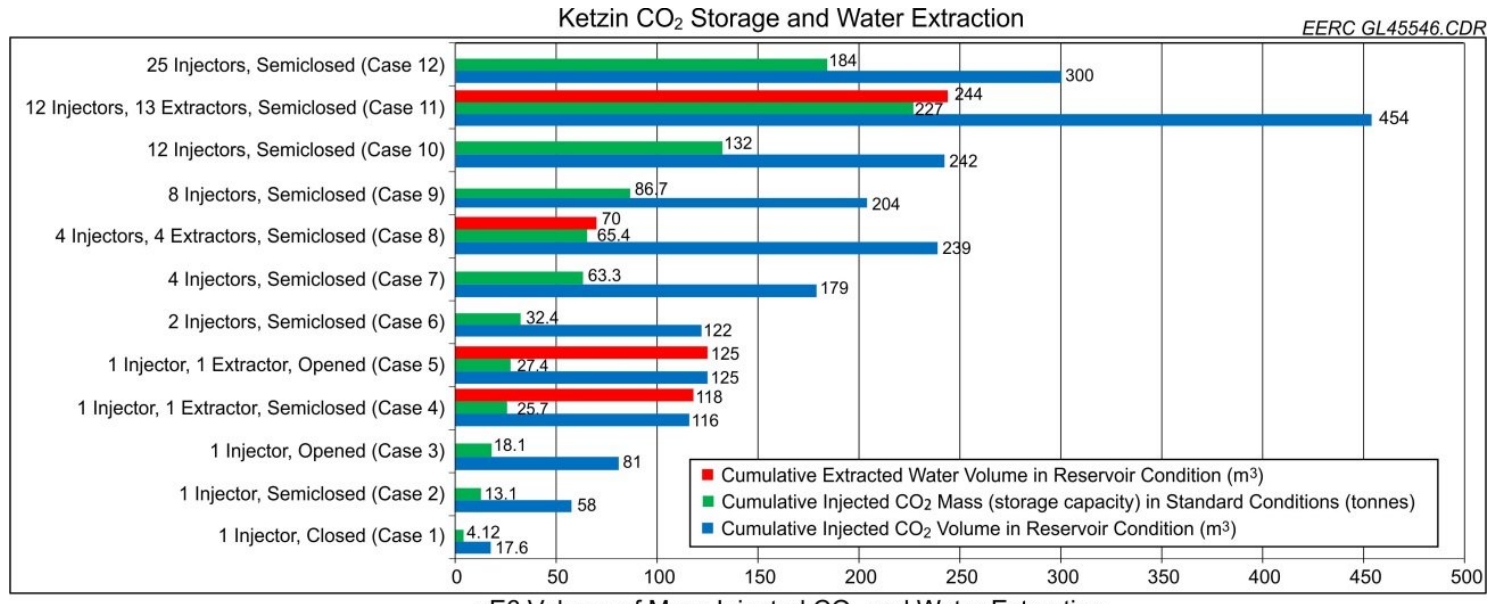

xE6 Volume of Mass Injected $\mathrm{CO}_{2}$ and Water Extraction

257 Fig. 3. Comparison of injected $\mathrm{CO}_{2}$ utilizing multiple combinations of injection and extraction wells. 


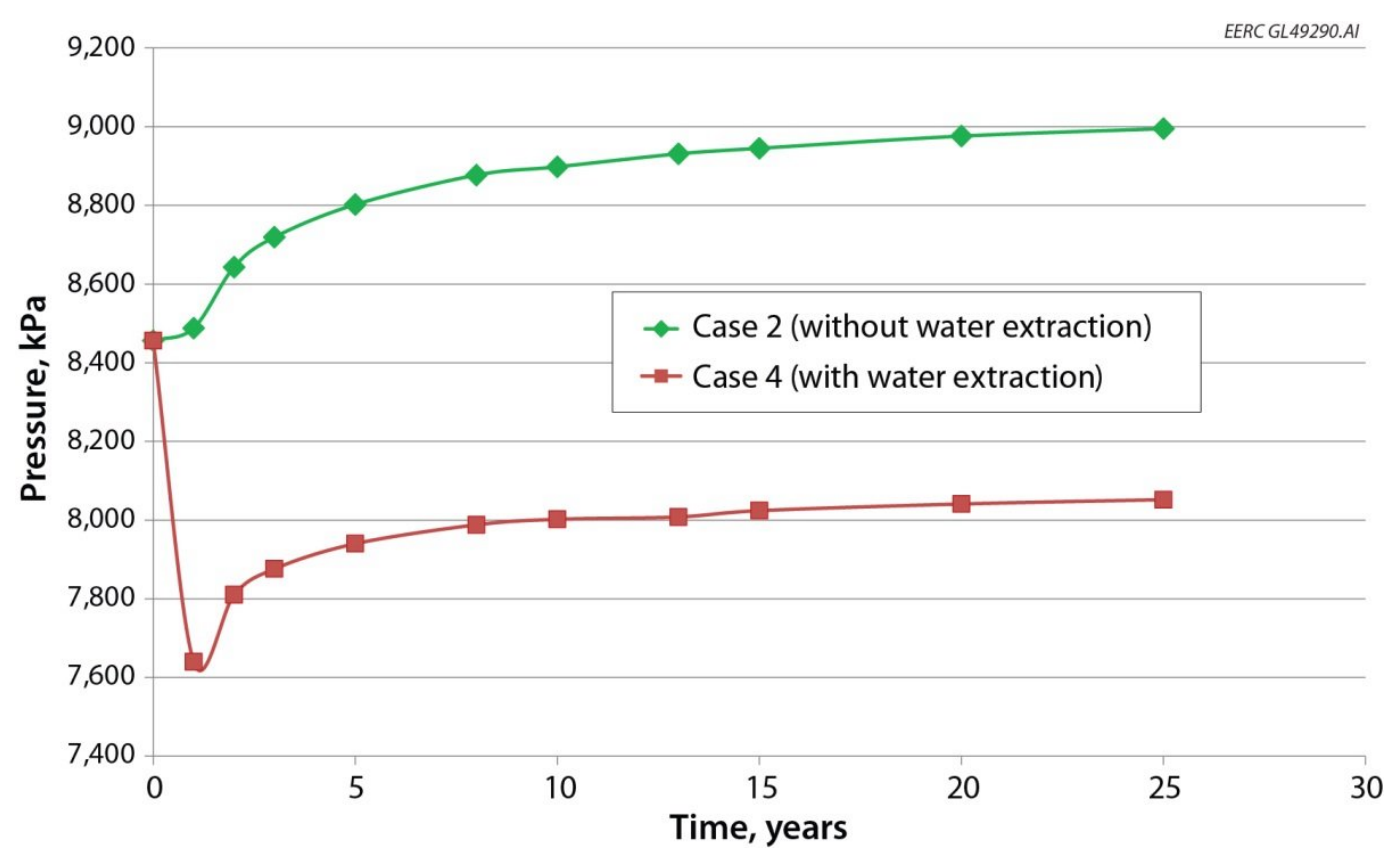

Fig. 4. Average reservoir pressure after 25 years of injection for Cases 2 and 4.

Fig. 5. Outline of plume extent after 25 years of injection for Cases 2 and 4 overlain grid to top. 


\subsubsection{Site Characterization}

The Zama F pool is one of over 700 hydrocarbon-bearing geologic structures in the Zama Subbasin located in extreme northwestern Alberta, Canada, and the site of a combined enhanced oil recovery (EOR) and storage project operated by Apache Canada, with the Energy \& Environmental Research Center (EERC) through the PCOR Partnership Program. Since December 2006, Apache Canada has been injecting acid gas (approximately $70 \% \mathrm{CO}_{2}+30 \% \mathrm{H}_{2} \mathrm{~S}$ ) for the simultaneous purpose of EOR, $\mathrm{H}_{2} \mathrm{~S}$ disposal, and $\mathrm{CO}_{2}$ storage. The Keg River pinnacle reefs typically consist of variably dolomitized carbonate and are surrounded and overlain by the very tight anhydrite Muskeg Formation that acts as a cap rock, effectively forming a closed system. A large variation in both porosity and permeability is observed with a decrease in both properties toward the reef tops. The principal rock types include various carbonate lithologies, including wackestone, packstone, floatstone, and rudstone with varying degrees of alteration due to secondary leaching and dolomitization. Porosity type varies from intercrystalline to microfractures in Table 4 (Burke, 2009).

Table 4. Reservoir Properties for the Zama F Pool Pinnacle Reef

\begin{tabular}{lll}
\hline Property & Value & Source \\
\hline Effective Porosity & $0.03 \%-17 \%$ & Log derived \\
Permeability & 0.001 to $2127 \mathrm{mD}$ & Log derived \\
Thickness & $240 \mathrm{~m}$ & Burke, 2009 \\
Depth, structure top & $1427 \mathrm{~m}$ & Burke, 2009 \\
Temperature & $71.1^{\circ} \mathrm{C}$ & Operator communication \\
Initial Reservoir Pressure & $14,450 \mathrm{kPa}$ & Operator communication \\
Average $\mathrm{CO}_{2}$ Density & $653.43 \mathrm{~kg} / \mathrm{m}^{3}$ & Massachusetts Institute of Technology, 2011 \\
TDS* & $180,000 \mathrm{ppm}$ & Operator communication \\
\hline
\end{tabular}

\subsubsection{Modeling}

The Zama model was a special case where an advanced workflow was followed because of available information. Core-calibrated multimineral petrophysical analysis was performed on wireline logs. Borehole image logs were used to more accurately identify the different facies and determine each facies' properties along the wellbores. Seismic attribute data interpretations were used to identify the reef versus nonreef facies to aid in the distribution of the facies in the reservoir model. Properties were then spatially distributed throughout the model using a combination of multiple-point statistics and object-modeling workflows to produce equiprobable reef facies, structure, and volumetric realizations (Fig. 6). $\mathrm{P}_{10}, \mathrm{P}_{50}$, and $\mathrm{P}_{90}$ geologic models were constructed for Zama, based on the above workflow; however, only the $\mathrm{P}_{50}$ was used for numerical simulation. 


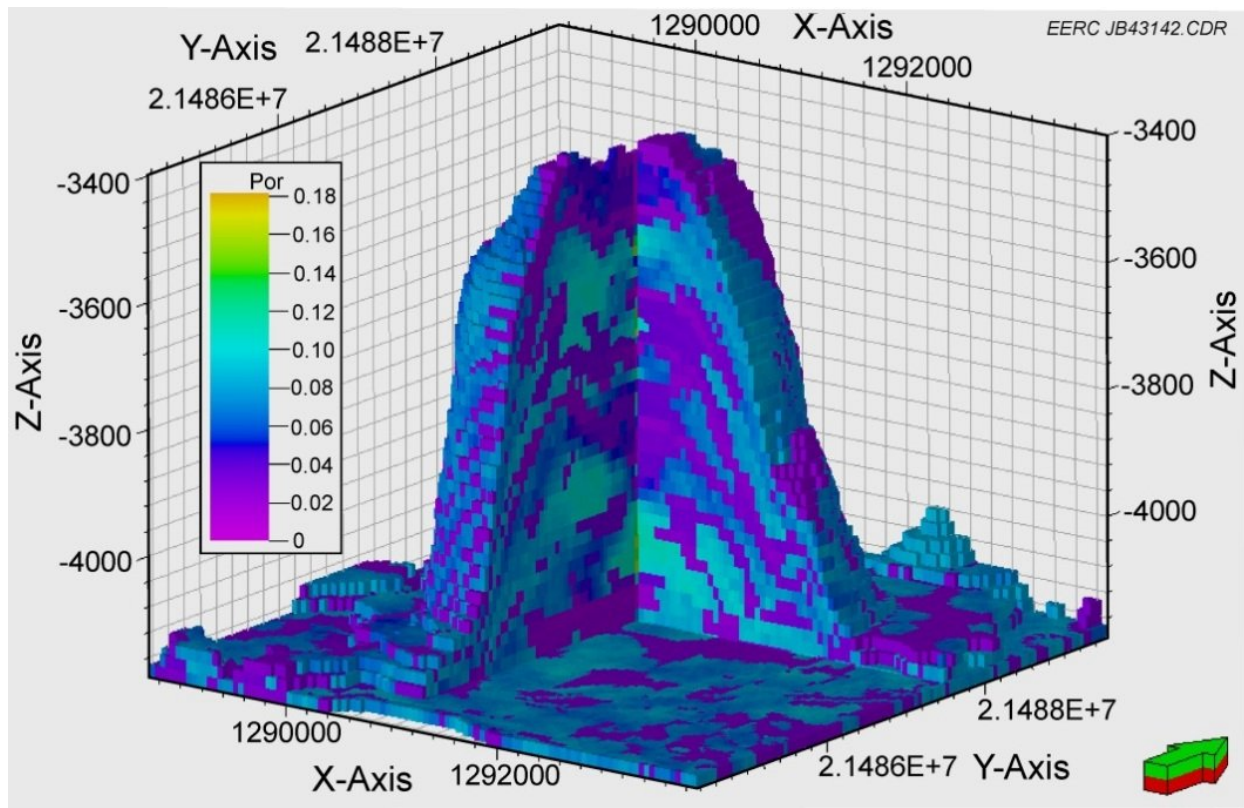

Fig. 6. 3-D view of porosity attributes with internal reef heterogeneity.

\subsubsection{Key Results}

Seven different cases of simultaneous $\mathrm{CO}_{2}$ injection and formation water extraction were tested (Table 5 and Fig. 7). In Case 1 , acid gas was injected at a base rate $(0.113 \mathrm{Mt} / \mathrm{year})$ without the extraction of formation water. In Cases 2-6, a water extraction well was placed in the bottom (water) zone of the reef structure. The results of Cases 1 and 2 show that the storage capacity increased from $0.05 \mathrm{Mt}$ to $0.62 \mathrm{Mt}$ with water extraction. The storage capacity also increased when the water extraction rate was decreased in Cases 3-5 because of a delay in gas breakthrough at the extraction well. Injection rates were doubled in Case 6, but this resulted in earlier $\mathrm{CO}_{2}$ breakthrough and lower capacity than Cases 3-5. With two water extractors in Case 7, early breakthrough was again observed, limiting total capacity. Overall, a pair of injection-extraction wells shows the best storage capacity for the Zama Site (IEA Greenhouse Gas R\&D Programme, 2012; Saini et al., 2013, Liu et al., 2014, Gao et al., 2014). 
Table 5. Cases Tested in Predictive Simulations for the Zama Site

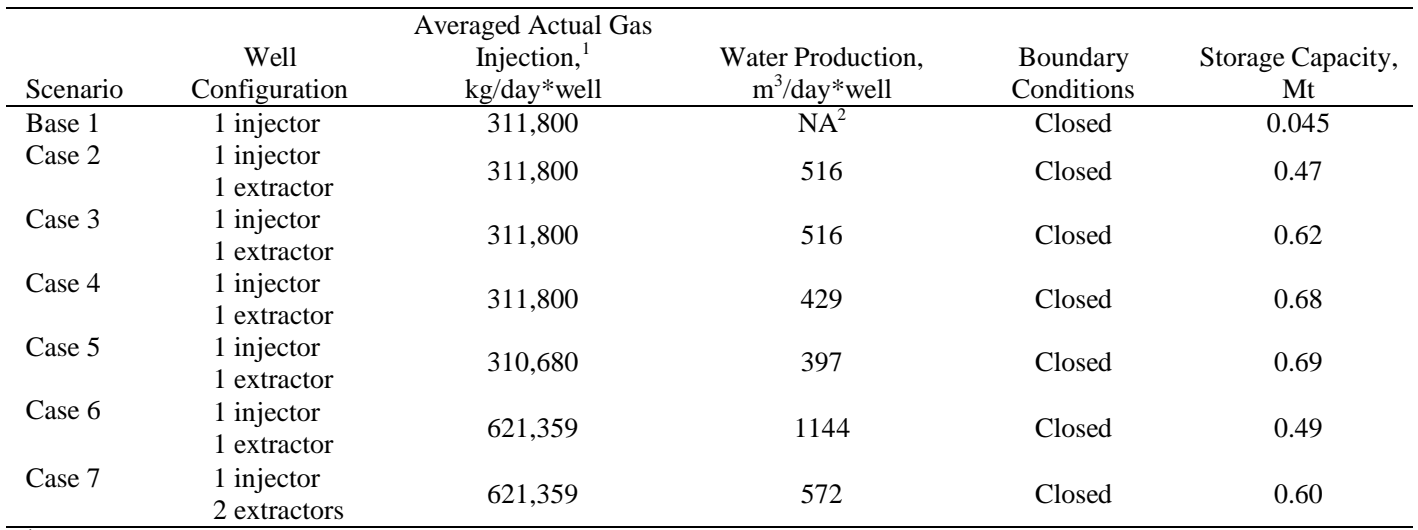

${ }^{1}$ Standard conditions $\left(15.5^{\circ} \mathrm{C}, 101.25 \mathrm{kPa}\right)$.

$319{ }^{2}$ Not applicable.

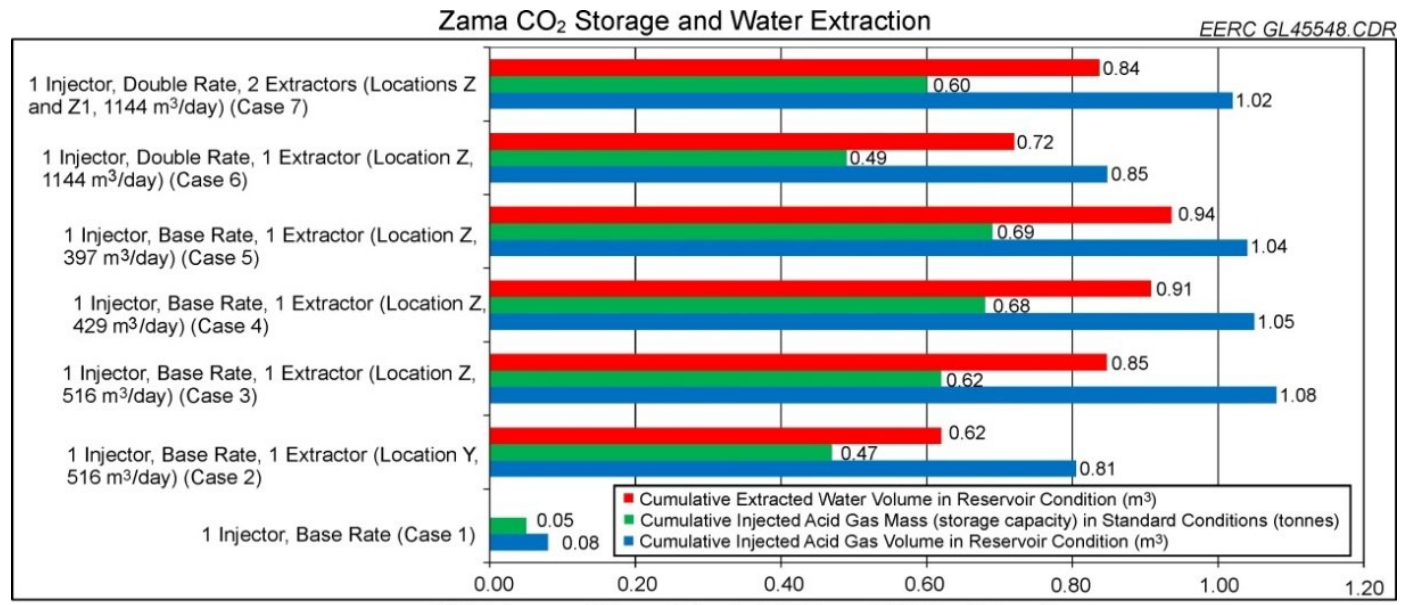

xE6 Volume of Mass Injected $\mathrm{CO}_{2}$ and Water Extraction

Fig. 7. Comparison of injected $\mathrm{CO}_{2}$ utilizing multiple combinations of injection and extraction wells.

\subsection{Gorgon Case Study}

\subsubsection{Site Characterization}

The Gorgon project is a joint venture to inject and store produced $\mathrm{CO}_{2}$ and is managed by oil companies Chevron, ExxonMobil, and Royal Dutch Shell, with partners Tokyo Gas, Osaka Gas, and Chubu Electric (Massachusetts Institute of Technology, 2011). The injection target is the Dupuy Formation, a clastic turbidite sequence $2500 \mathrm{~m}$ below the surface infrastructure on Barrow Island off the western coast of Australia. The project aims to inject approximately $3.8 \mathrm{Mt} /$ year through eight injection wells, with four water production wells located to the west of the site; injection is expected to begin in 2015 (Massachusetts Institute of Technology, 2011; Flett et al., 2008).

The island is located atop a large $(25 \times 38 \mathrm{~km})$, north-south-trending, double-plunging anticline. The injection target is 200-500 meters thick, comprising sandstones and siltstones deposited as turbidite and 
Four major subunits have been defined with lithology presented in Table 6. Data were scarce for the site for both modeling workflow and reservoir data, with basic results from modeling efforts reported by Flett et al. (2008). In order to develop the hypothetical injection plan for this study, additional data, including wireline logs from an exploratory well, were incorporated from Brantjes (2008).

Table 6. Unit Descriptions and Thicknesses from the Gorgon Site

\begin{tabular}{lll}
\hline Subunit & Lithology (from Brantjes [2008]) & Thickness, m \\
\hline Upper Dupuy & Bioturbated siltstone; poor quality & 111 \\
Upper Massive Sand & Medium-grained sandstone; high quality & 140 \\
Lower Dupuy & Fine-grained sandstone/siltstone to shale; fair quality & 190 \\
Basal Dupuy & Siderite-cemented fine-grained sandstone; poor quality & 95 \\
\hline
\end{tabular}

\subsubsection{Modeling}

341 Well locations and the structure on top of the Upper Massive Sand unit of the Dupuy Formation were used as baseline data according to Flett et al. (2008). As sufficient well logs or structure maps for additional subunits were not present, constant unit thickness was defined from unit boundaries on well logs from Brantjes (2008) (Table 7). The model size used by Flett et al. (2008) was found to be sufficient to contain the 3.3-3.8-million-tonnes/year injection without reaching the model boundaries. Since poor reservoir quality was encountered in wireline logs, facies were not assigned for the Basal Dupuy, and the unit is considered to behave as a lower seal. The Lower Dupuy was assigned facies using truncated Gaussian simulation, using parameters and techniques suggested by Flett et al. (2008), who stated that reservoir quality degrades from high on the north end to silty then shaley moving south. The Upper Massive Sand and Upper Dupuy zones were modeled using object modeling processes for fan-type deposits with thicknesses and prevalence by following the suggestions of Flett and others (2008) and Brantjes (2008). Facies were populated with porosity and permeability properties according to variograms from GSLIB (Deutsch and Journel, 1998); clastic slope/basin environments and porosity, effective porosity, and permeability values were from Brantjes (2008). Most of the properties and parameters, including saturations, relative permeability curves, boundary conditions, and initial reservoir pressure for modeling and simulations, were based on publications (Table 7, Fig. 8) (Brantjes, 2008), and notably, the proposed location of the injection and production wells followed the study of Flett et al. (2008).

Table 7. Gorgon Model Properties

\begin{tabular}{lll}
\hline Total Porosity & Value & Source \\
\hline Effective Porosity & $0 \%-25.3 \%$ & Brantjes, 2008 \\
Permeability & $0-272 \mathrm{mD}$ & Brantjes, 2008 \\
Depth, top of Upper Dupuy & $2245 \mathrm{~m}$ & Flett et al., 2008 \\
Pressure, average & $25,165 \mathrm{kPa}$ & Flett et al., 2008 \\
Temperature, average & $161^{\circ} \mathrm{C}$ & Colombo et al., 2010 \\
Average $\mathrm{CO}_{2}$ Density & $528.1 \mathrm{~kg} / \mathrm{m}^{3}$ & Massachusetts Institute of Technology, 2011 \\
Variogram Range, long & 1346 & IEA Greenhouse Gas R\&D Programme, 2009 \\
Variogram Range, short & 367 & IEA Greenhouse Gas R\&D Programme, 2009 \\
TDS & $7096-28,615 \mathrm{ppm}$ & Trupp, 2011 \\
\hline
\end{tabular}



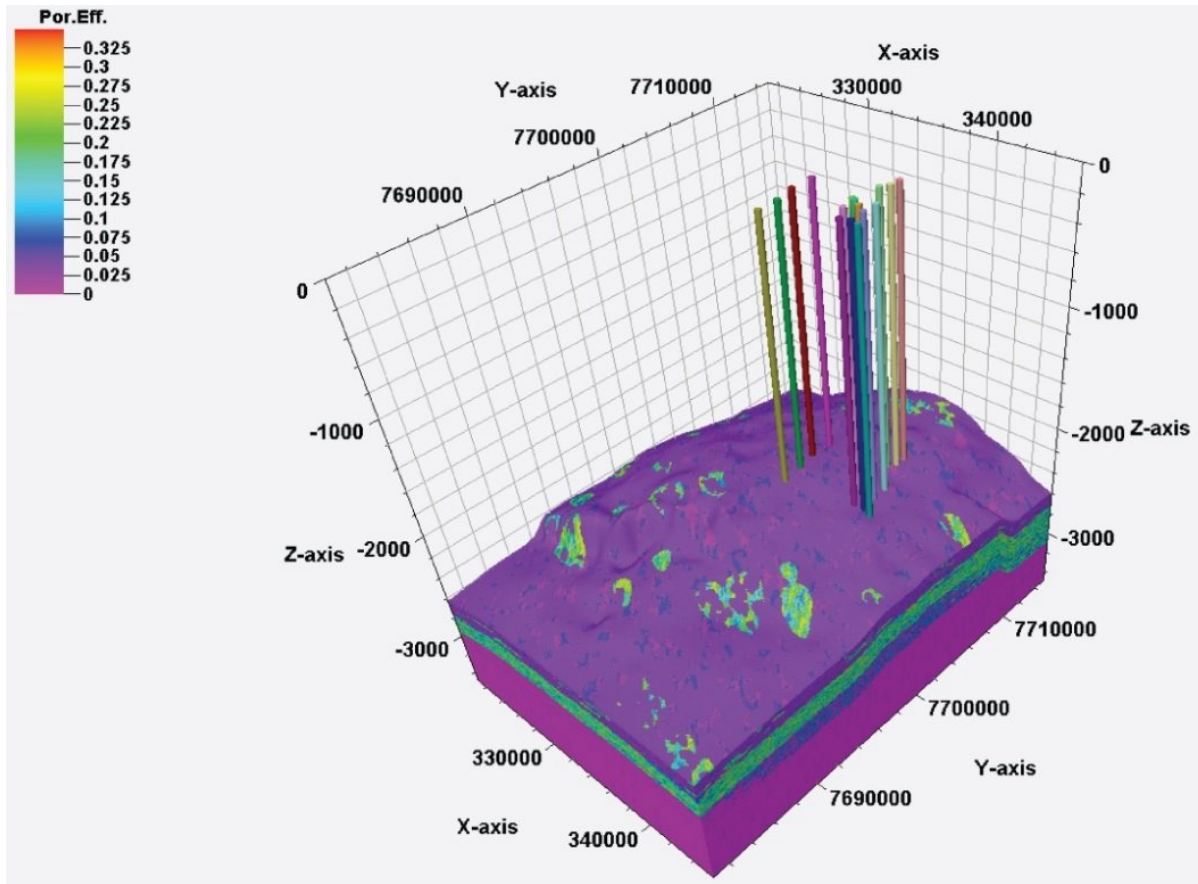

EERC RK43121.CDR

Fig. 8. 3-D representation of the Gorgon reservoir model with location of injection and extraction wells.

\subsubsection{Key Results}

Seven hypothetical cases were simulated by using the planned eight injection wells and four extraction wells (Table 8 and Fig. 9). The base scenario injected $0.5 \mathrm{Mt} / \mathrm{year}$ (base rate) through each well for investigational periods of 25 and 50 years, for a total of 100- and 200-Mt $\mathrm{CO}_{2}$ injections. The effects of extraction on capacity were minimal in Cases $1-5$, as the reservoir has excellent injectivity and capacity, meaning that the upper limit of injection was not achieved through these simulations. For this reason, the total storage in Cases 1-5 is quite linear with regard to injection rate and period. Cases 6 and 7 sought to maximize the injection rate, beginning with 7.5 times the base yearly injection rate, or $3.75 \mathrm{Mt} /$ year per well for 25 years. Because of the higher injection rates, pressure increases near the injection wells were expected to cause issues that may be alleviated by water extraction. Simulations under this scenario resulted in storage capacities of $551 \mathrm{Mt}$ without water extraction, which increased to $637 \mathrm{Mt}$ with water extraction, an increase of 16\% (IEA Greenhouse Gas R\&D Programme, 2012; Liu et al., 2013).

Pressure management through water extraction proved very consistent, with pressures reduced by approximately 10\% from Case 1 to Case 2 (Fig. 10) after 13 years of injection. Over the injection and extraction period, the pressure differences increased because of the effect from water extraction. However, with more $\mathrm{CO}_{2}$ being injected, reservoir pressure started increasing slightly. The difference in plume size was relatively small between Cases 1 and 2 , differing by a negligible percentage. The size difference between Cases 6 and 7 was a notable 10.1\% with maximum injection scenarios (Fig. 11) (Liu 
381

382

Table 8. Case Scenarios and Resulting Storage Capacities for Gorgon

\begin{tabular}{|c|c|c|c|c|c|c|}
\hline Scenario & $\begin{array}{l}\text { Well } \\
\text { Configuration }\end{array}$ & $\begin{array}{l}\text { Target } \\
\text { Injection } \\
\text { Rate/Well, } \\
\text { Mt/year } \\
\end{array}$ & $\begin{array}{l}\text { Averaged Actual } \\
\text { Gas Injection } \\
\text { Rate/Well, } \\
\text { kg/day } \\
\end{array}$ & $\begin{array}{l}\text { Water } \\
\text { Production } \\
\text { Rate/Well, } \\
\mathrm{m}^{3} / \text { day } \\
\end{array}$ & $\begin{array}{l}\text { Injection } \\
\text { Period, yr }\end{array}$ & $\begin{array}{l}\text { Storage } \\
\text { Capacity, } \\
\text { megatonnes } \\
\end{array}$ \\
\hline Case 1 (base case) & 8 injectors & 0.5 & $10,661,700$ & NA & 25 & 97.3 \\
\hline Case 2 & $\begin{array}{l}8 \text { injectors } \\
4 \text { extractors }\end{array}$ & 0.5 & $10,661,700$ & $215,120,000$ & 25 & 97.5 \\
\hline Case 3 & 8 injectors & 0.5 & $10,661,700$ & NA & 50 & 195 \\
\hline Case 4 & $\begin{array}{l}8 \text { injectors } \\
4 \text { extractors }\end{array}$ & 0.5 & $10,661,700$ & $334,919,000$ & 50 & 196 \\
\hline Case 5 & $\begin{array}{l}8 \text { injectors } \\
4 \text { extractors }\end{array}$ & 0.25 & $5,330,830$ & $396,606,000$ & 50 & 97.5 \\
\hline Case 6 & 8 injectors & 3.75 & $60,400,000$ & NA & 25 & 551 \\
\hline Case 7 & $\begin{array}{l}8 \text { injectors } \\
4 \text { extractors }\end{array}$ & 3.75 & $69,900,000$ & $261,802,000$ & 25 & 637 \\
\hline
\end{tabular}

383

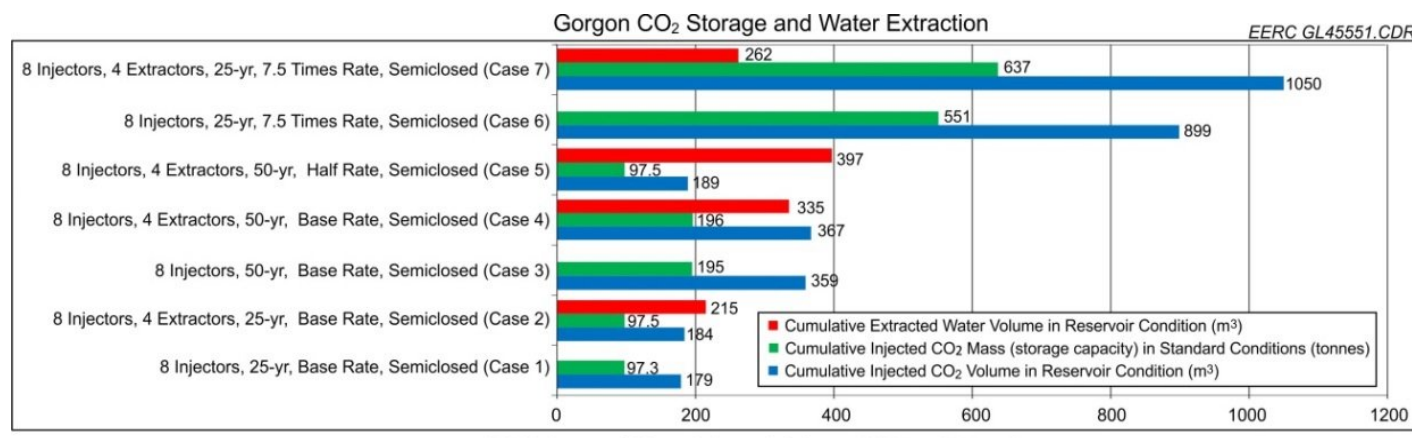

xE6 Volume of Mass Injected $\mathrm{CO}_{2}$ and Water Extraction

Fig. 9. Comparison of injected $\mathrm{CO}_{2}$ utilizing multiple combinations of injection and extraction wells. 


\section{x}

387

388 Fig. 10. Average reservoir pressure after 25 years of injection for Cases 1 and 2. EERC GL 49289.AI

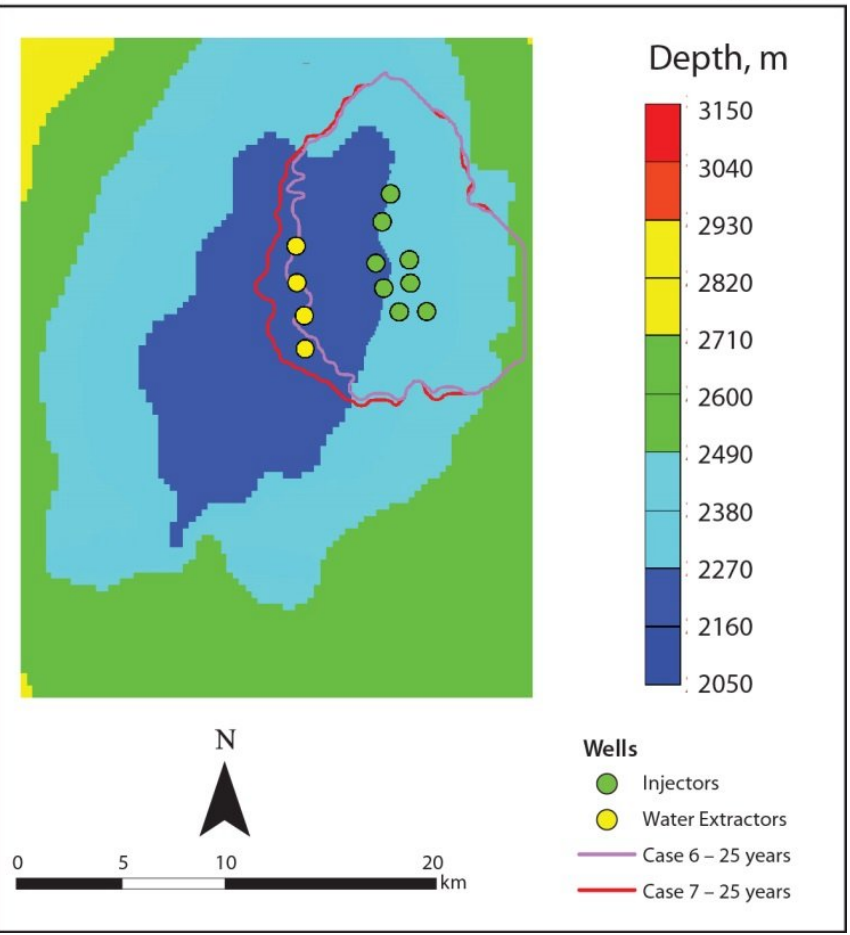




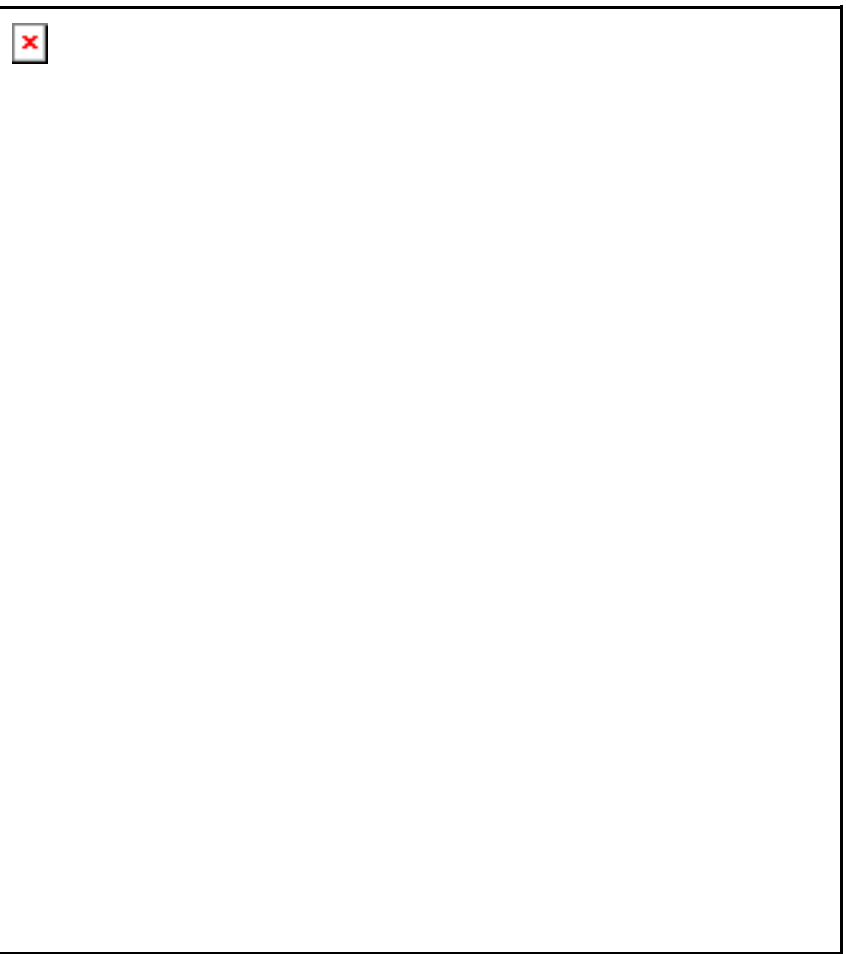

Fig. 11. Map of injection and extraction wells on Barrow Island with plume outlines of cases.

\subsection{Teapot Dome Case Study}

\subsubsection{Site Characterization}

Teapot Dome, also known as Naval Petroleum Reserve 3 or the Rocky Mountain Oilfield Testing Center (RMOTC), is a demonstration site near Casper, Wyoming. Teapot Dome is a stacked sedimentary sequence on the western flank of the Powder River Basin present as an elongated anticline and is adjacent to the Salt Creek Anticline, a commercial oil field currently undergoing $\mathrm{CO}_{2}$ EOR. Over 1300 wells penetrate the structure at the Teapot Dome, which has historic production within the Tensleep and Frontier sandstones and reserves in the Muddy sandstone. Additionally, saline aquifers are located in both clastic and carbonate beds, including the Dakota/Lakota and Madison Formations (Table 9). Produced water from oil field activities at Teapot Dome is of extremely high quality and has many uses in the semiarid Powder River Basin.

Table 9. Unit Descriptions for the Teapot Dome Site

\begin{tabular}{ll}
\hline Formation & Interpreted Lithology \\
\hline Frontier & Interbedded sandstones and shales, deltaic \\
Muddy & Sandstone body, nearshore marine \\
Dakota & Sandstone bodies, nearshore marine \\
Lakota & Sandstone bodies, nearshore marine \\
Tensleep & Interbedded sandstone and dolomite, sandstones primarily eolian \\
Madison & Variable reservoir quality, shallow shelf \\
\hline
\end{tabular}


Study efforts were focused on the Dakota and Lakota Formations for this site, although it is recognized that utilizing several formations in the stratigraphic section is optimal for storing large volumes of $\mathrm{CO}_{2}$. Because of historic hydrocarbon production, characterization of the site has resulted in large volumes of data, and the field continues to operate as a demonstration and experimental site, as oil production has declined to unprofitable levels. Interest in $\mathrm{CO}_{2}$ EOR is present because of successful $\mathrm{CO}_{2} \mathrm{EOR}$ ongoing in the adjacent Salt Creek Field since 2003, where 6583 tonnes of $\mathrm{CO}_{2}$ a day is injected, totaling 6.6 million tonnes as of February 2010 (Forster, 2006).

\subsubsection{Modeling}

A data set of Teapot Dome information, including well locations, picked formation tops, and well logs, was available in CD format from RMOTC (Rocky Mountain Oilfield Testing Center, 2007). Formation tops were used to form a high-resolution structural model of each horizon. Unfortunately, characterization information gleaned from literature review was not conducive to direct application in modeling, and fullscale petrophysical interpretation of the site is beyond the scope of this study. A limited amount of data collection has been processed by Milliken (2007) regarding geothermal resources and water quality, and a historical perspective and field overview were performed by Curry (1977). Because of the lack of petrophysical data at Teapot Dome, a deterministic model was developed to include reported or derived rock properties collected through core analysis, including porosity and permeability. Only one realization was modeled because of a lack of input data. The geologic model was developed (Fig. 12) based on published data (Table 10) (Milliken, 2007; Curry, 1977; Rocky Mountain Oilfield Testing Center, 2011).

The injection and production wells used in the models were a combination of existing wells in the field and hypothetical wells based on the geologic structure and geology for these investigations. 


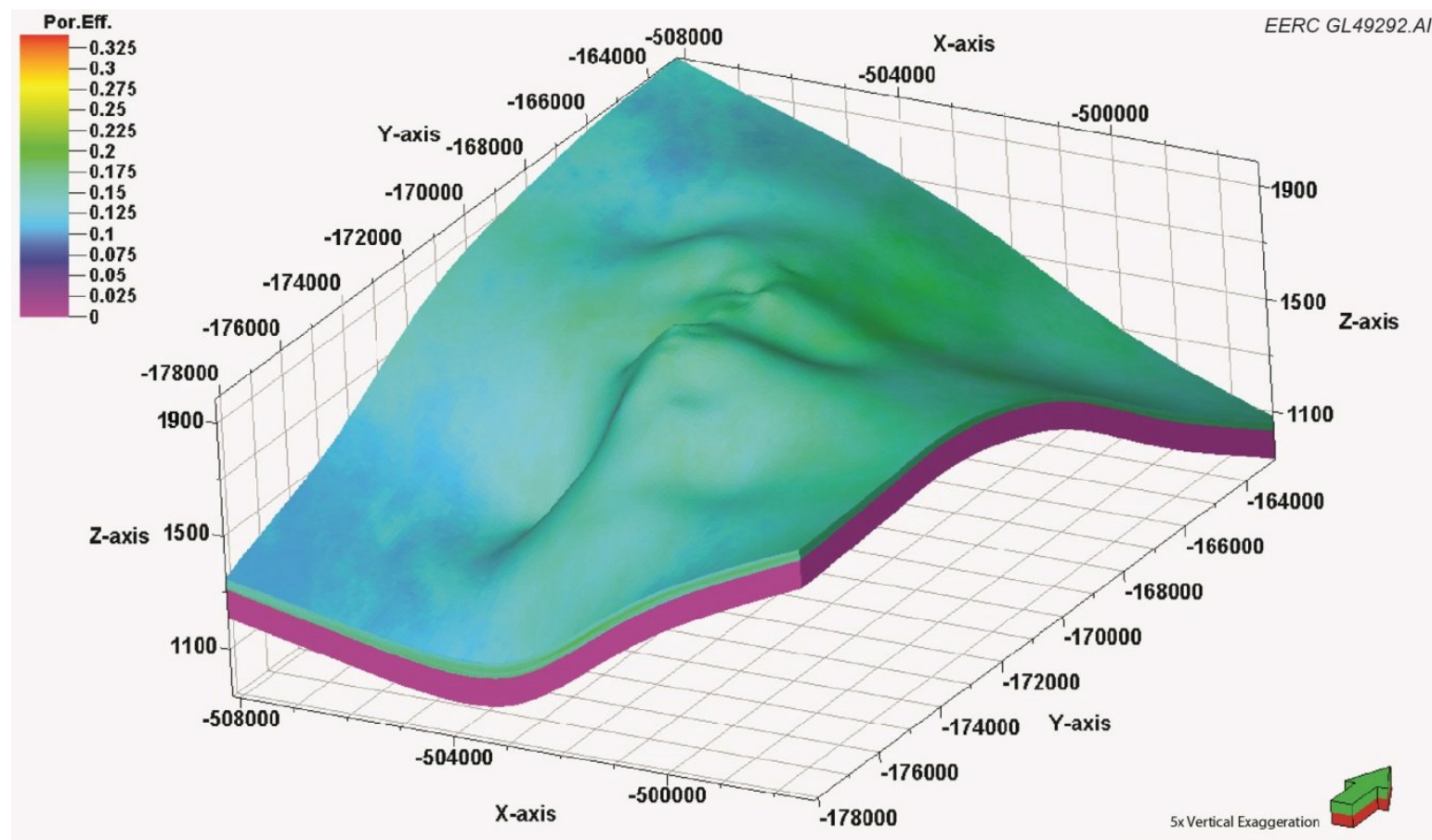

428 Fig. 12. 3-D view of the Teapot Dome Dakota model showing the porosity attribute.

Table 10. Reservoir Properties of the Dakota and Lakota Formations

\begin{tabular}{lll}
\hline Property & Value & Source \\
\hline Effective Porosity & $0 \%-25.3 \%$ & IEA Greenhouse Gas R\&D Programme, 2009 \\
Permeability & $0.4-319 \mathrm{mD}$ & IEA Greenhouse Gas R\&D Programme, 2009 \\
Thickness & $40 \mathrm{~m}$ & Rocky Mountain Oilfield Testing Center, 2007 \\
Depth, structure top & $1450 \mathrm{~m}$ & Rocky Mountain Oilfield Testing Center, 2007 \\
Temperature & $65.5^{\circ} \mathrm{C}$ & Milliken, M., 2007* \\
Pressure & $\sim 11,000 \mathrm{kPa}$ & Milliken, M., 2007* \\
Average $\mathrm{CO}_{2}$ Density & $163.23 \mathrm{~kg} / \mathrm{m}^{3}$ & Massachusetts Institute of Technology, 2011 \\
Variogram Range, long & 6792 & IEA Greenhouse Gas R\&D Programme, 2009 \\
Variogram Range, short & 1852 & IEA Greenhouse Gas R\&D Programme, 2009 \\
TDS & $9500 \mathrm{ppm}$ & Rocky Mountain Oilfield Testing Center, 2011 \\
\hline
\end{tabular}

\subsubsection{Key Results}

Injection/extraction analysis of the Dakota/Lakota Formation at Teapot Dome was investigated through a total of five simulations (Table 11 and Fig. 13). The boundary of the domain was set as semiclosed to reflect the geology with partial aquifer support from surroundings. The base injection target rate used for the site was $1 \mathrm{Mt} / \mathrm{year}$. The baseline simulation (Case 1) without extracted water resulted in a total storage capacity of 5.2 Mt for the site over 25 years, which is significantly lower than the injection target. In Case 3, one water extractor was added; this scenario resulted in a storage capacity of $11.1 \mathrm{Mt}$, more than doubling the single injection well results. Further, these results indicate that utilizing an injection-extraction well pair is a more efficient situation than utilizing two injection wells alone (Case 2). 
Table 11. Case Scenarios and Resulting Storage Capacities for Teapot Dome

\begin{tabular}{|c|c|c|c|c|}
\hline Scenario & Well Configuration & $\begin{array}{l}\text { Averaged Actual } \\
\text { Gas Injection } \\
\text { Rate/Well, kg/day }\end{array}$ & $\begin{array}{l}\text { Water Production } \\
\text { Rate/Well, } \mathrm{m}^{3} / \text { day }\end{array}$ & $\begin{array}{l}\text { Storage Capacity, } \\
\text { megatonnes }\end{array}$ \\
\hline Case 1 (base case) & 1 injector & 565,128 & NA & 5.2 \\
\hline Case 2 & 2 injectors & 836,848 & NA & 7.6 \\
\hline Case 3 & $\begin{array}{l}1 \text { injector } \\
1 \text { extractor }\end{array}$ & $1,212,810$ & 1657 & 11.1 \\
\hline Case 4 & $\begin{array}{l}1 \text { horiz. injector } \\
1 \text { horiz. extractor }\end{array}$ & $2,090,498$ & 6701 & 19.1 \\
\hline Case 5 & 2 horiz. injectors & $1,953,238$ & N/A & 17.8 \\
\hline
\end{tabular}

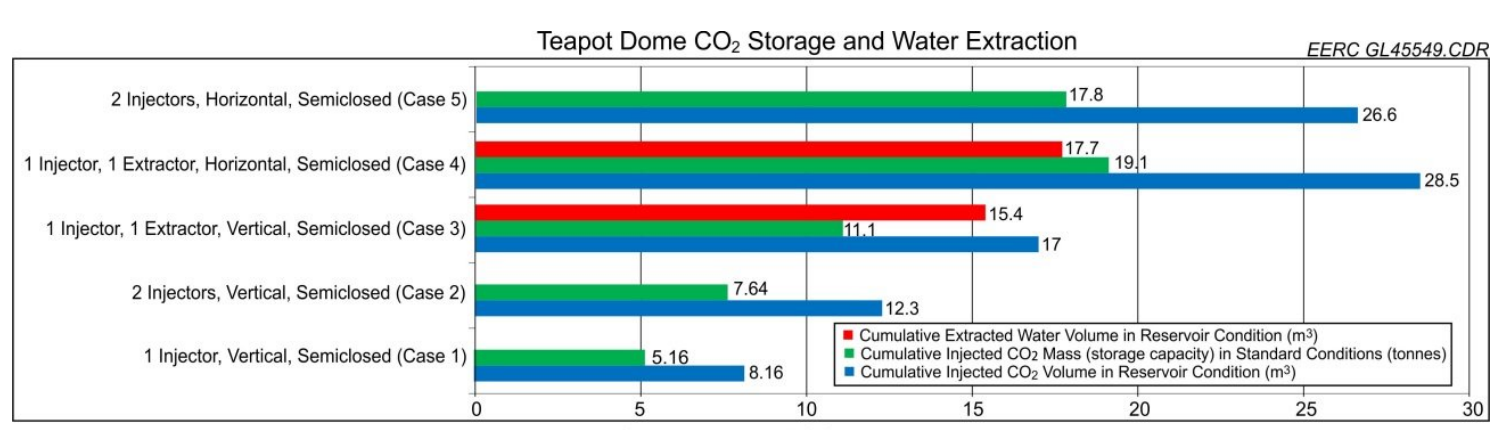

Fig. 13. Comparison of injected $\mathrm{CO}_{2}$ utilizing multiple combinations of injection and extraction wells.

An alternative method of increasing storage capacity is using horizontal wells in place of vertical wells. In Case 4, two 1-km-long horizontal wells were utilized: one for injection and one for water extraction. This case resulted in $19.1 \mathrm{Mt}$ of storage capacity, nearly doubling the capacity of using a vertical well pair. In addition to the increase in storage capacity, the plume size increased by $44 \%$ from Case 3 to Case 4 (IEA Greenhouse Gas R\&D Programme, 2012; Liu et al., 2013), with an associated drop in overall reservoir pressure, which means that horizontal wells play a significant role in enhancing $\mathrm{CO}_{2}$ storage through lateral injection and extraction performance. For comparison, Case 5 was run with two $1-\mathrm{km}$-long horizontal injection wells instead of an injector-extractor pair; this scenario resulted in 17.8 Mt of storage capacity over the 25 -year injection period, which was about $7 \%$ less storage than the injector-extractor pair (Fig 14). Hence, storage capacity was enhanced $7 \%$ by using water extraction instead of horizontal injection in comparing Cases 4 and 5. The results from these five cases indicate that storage capacity can be further improved in certain scenarios by utilizing injection-extraction pairs rather 


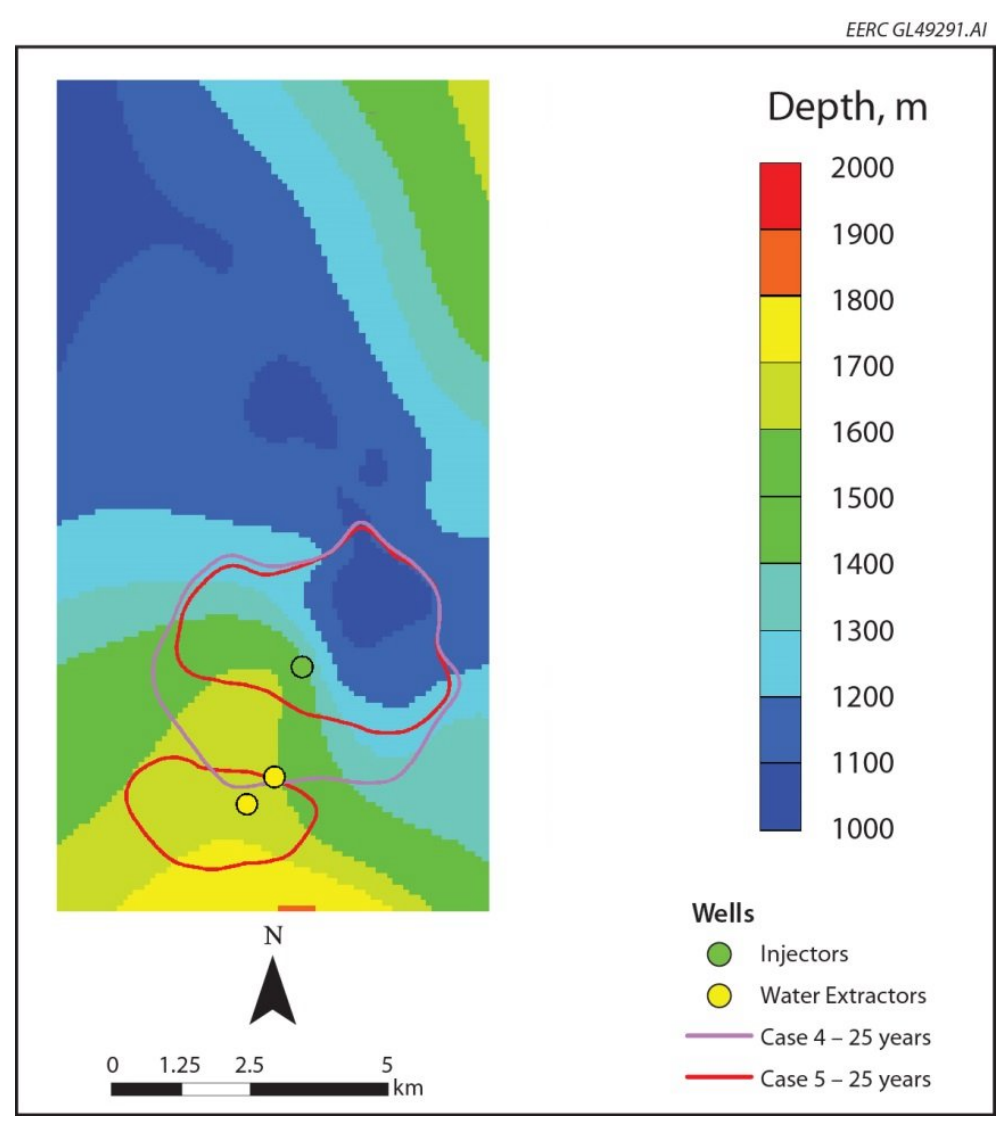

Fig. 14. Plume distribution of Teapot Dome Cases 4 and 5 illustrating the effects on plume size from the utilization of horizontal and vertical extraction wells.

\section{2}

\section{Conclusions and Future Works}

Extracting water from a $\mathrm{CO}_{2}$ storage reservoir was observed to have variable effects based on the specific nature of reservoir rock and reservoir boundary conditions as well as operational factors such as injection/extraction management and placement of wells. The assumption of achieving a 1:1 ratio of injected $\mathrm{CO}_{2}$ to extracted water was generally appropriate for increasing $\mathrm{CO}_{2}$ storage capacity. However, in order to perform pressure or plume management tasks, the volume of water that must be removed from the reservoir was found to be four or more times greater in some cases.

Water extraction was found to be imperative to control pressure and increase storage space in closed systems and likely will provide benefit to most semiclosed, bounded reservoirs if water disposal or use is not highly prohibitive.

The Ketzin-based model provided a stage on which to test boundary conditions and the impact of increasing injectors and/or producers across a geologic structure. More injectors accessed more of the fluvial reservoir, and extractors were beneficial in storage capacity increases, on the order of $98 \%$ more storage space and a $32 \%$ smaller plume area. 
The most dramatic results were found in closed reservoir simulations from the Zama site, where storage capacity could be increased by nearly $1300 \%$ in a single pinnacle reef structure with proper well placement. Although individually small, capable of holding approximately 690,000 tonnes of $\mathrm{CO}_{2}$, the Zama Field has hundreds of similar structures, which could be developed in the same way to meet the 1-million-tonne/yr injection goal. A key observation in storage scenarios such as the Zama F pool was that higher injection rates led to faster breakthrough and, therefore, limited lower storage capacity.

The Gorgon-based model tested various strategies of the proposed injection design of eight injectors and four water extraction wells. Water production at the site was found to have little impact because of the site's capacity, injectivity, and reservoir quality being much greater than the injection scheme; therefore, alleviation of reservoir pressure to aid in pressure management was not necessary. Only when injection rates were increased by 7.5 times did water extraction impact the site. Although water extraction had essentially no impact on potential storage capacity, it was still found to influence plume behavior and pressure propagation in such a way as to be useful for plume management.

The opposite of the Gorgon-based model was encountered in the case of the Teapot Dome-based model, where injection design quickly approached reservoir limits. For sites such as this, water extraction is beneficial, and designs incorporating pressure management were found to produce significant gains in storage capacity. The impact of horizontal wells was tested in the Teapot Dome model, in which lateral wells accessed the reservoir better and provided enhanced performance from vertical injector-producer pairs.

Simulations of hypothetical injections at the Ketzin and Teapot Dome sites showed potential $\mathrm{CO}_{2}$ storage capacity increases of approximately double (197\% and $204 \%$, respectively) from formation water extraction. In each of these cases, capacity and the relative influence on plume behavior could be enhanced by modifying the injection scheme. The Ketzin simulations initially showed that two $\mathrm{CO}_{2}$ injection wells outperformed an injection extraction pair. However, it was found that if the number of wells was substantially increased to a 25 -spot well pattern, the combination of 12 injection and 13 extraction wells outperformed 25 injection wells by $123 \%$ and did so while removing approximately half as much water (by volume) as $\mathrm{CO}_{2}$ injected. At the Teapot Dome site, it was found that the use of horizontal well pairs could further increase the impact of water extraction and increase the $\mathrm{CO}_{2}$ storage capacity. Overall capacity was increased by $367 \%$ over the base case single vertical injection well and thus represents an additional 163\% increase over the injection-extraction pair. In both these cases, optimizing simulations to achieve pressure maintenance or plume management generally resulted in decreased reservoir storage capacity, with a significant increase in the volume of extracted water.

The characterizations of four sites diverge from geologic structure and heterogeneity that resulted in different effects on the $\mathrm{CO}_{2}$ storage capacity. Sites were chosen to reflect differences in reservoir behavior (open vs. closed boundaries), geologic properties and heterogeneity, structure, modern climate, and data availability. It was observed that variation of temperature and pressure due to the geology and depth of the sites directly influenced the $\mathrm{CO}_{2}$ storage capacity estimation because the $\mathrm{CO}_{2}$ density is highly sensitive to these factors. This is the primary reason that the $\mathrm{CO}_{2}$ density in the four cases changed from $163 \mathrm{~kg} / \mathrm{m}^{3}$ (Teapot Dome site) to $528 \mathrm{~kg} / \mathrm{m}^{3}$ (Gorgon site) and about $650 \mathrm{~kg} / \mathrm{m}^{3}$ (Zama and Ketzin sites). However, these four case studies illustrate the wide range of results that may be possible and that geologic and reservoir engineering factors may both have a large influence on the final results. It can also be said that if it is feasible to utilize a large number of injection and extraction wells, overall storage may be increased by a large margin, even in high-quality storage reservoirs.

The influence of water extraction on the migration of pressure and free-phase $\mathrm{CO}_{2}$ plumes was observed in each of the open-system sites. However, this influence was moderated by other factors such as geologic structure and local reservoir heterogeneities. The utilization of water extraction for the purpose of reservoir management is best applied to reservoirs with low structural control. In the case of the Ketzin site (a dome-shaped structure), water extraction did not appear to have a strong effect on the structure-dominated $\mathrm{CO}_{2}$ movement. However, in the case of a relatively flat- structured reservoir (the 
Gorgon and Teapot Dome sites), $\mathrm{CO}_{2}$ plume and pressure management results were significantly affected by water extraction. At the Gorgon and Teapot Dome sites, $\mathrm{CO}_{2}$ injection with fluid extraction increased storage capacity by $50 \%$, with only a $10 \%$ increase in plume size in several scenarios. In other scenarios, fluid extraction resulted in a $10 \%$ to $20 \%$ pressure reduction, with only a $5 \%$ increase in plume size. Therefore, the $\mathrm{CO}_{2}$ plume movement trended in the direction of fluid extraction during this process, especially by the geologic structure and local reservoir heterogeneities. In all cases, $\mathrm{CO}_{2}$ storage capacity was increased with a reduction in the overall reservoir pressure, suggesting that water extraction can play a role in maximizing the utility of large-scale $\mathrm{CO}_{2}$ storage facilities in the future as more projects are developed.

Extracted water treatment, utilization, and regulation need to be much investigated based on the variation of the salinities by following the recommendations in the detailed report (IEA Greenhouse Gas $\mathrm{R} \& D$ Programme, 2012). Developing formulaic methodology to estimate $\mathrm{CO}_{2}$ storage capacity specific to the use of formation water extraction as a reservoir management strategy based on the more depositional environments and reservoir types are highly encouraged for the future study. This would allow for rapid assessment of the benefits of extraction on known and future $\mathrm{CO}_{2}$ storage targets.

\section{Acknowledgments}

This material is based upon work supported by the U.S. Department of Energy National Energy Technology Laboratory and the IEA Greenhouse Gas R\&D Programme under Award No. DE-FC2605NT42592. Computer Modelling Group Ltd. and Schlumberger are gratefully acknowledged for providing software. Thanks also go to former colleagues Mr. Damion Knudsen and Dr. Dayanand Saini for assistance with modeling and simulation work.

\section{Disclaimer}

This report was prepared as an account of work sponsored by an agency of the United States Government. Neither the United States Government nor any agency thereof, nor any of their employees, makes any warranty, express or implied, or assumes any legal liability or responsibility for the accuracy, completeness, or usefulness of any information, apparatus, product, or process disclosed, or represents that its use would not infringe privately owned rights. Reference herein to any specific commercial product, process, or service by trade name, trademark, manufacturer, or otherwise does not necessarily constitute or imply its endorsement, recommendation, or favoring by the United States Government or any agency thereof. The views and opinions of authors expressed herein do not necessarily state or reflect those of the United States Government or any agency thereof.

\section{References}

Bachu, S., Adams, J.J., 2003. Sequestration of $\mathrm{CO}_{2}$ in geological media in response to climate change: Capacity of deep saline aquifers to sequester $\mathrm{CO}_{2}$ in solution. Energy Conversion and Management 44(20), 3151-3175.

Brantjes, J., 2008. Formation evaluation for $\mathrm{CO}_{2}$ disposal. In: SPWLA 49th Annual Logging Symposium, Edinburgh, Scotland, May $25-28$.

Burke, L., 2009. PCOR Project—Apache Zama F pool acid gas EOR \& $\mathrm{CO}_{2}$ storage. Report prepared by RPS Energy Canada for the Energy \& Environmental Research Center, September. 
Burtin, M., Bryant, S.L., 2009. Surface dissolution: Minimizing groundwater impact and leakage risk simultaneously. Energy Procedia 1(1), 3707-3714.

Buscheck, T.A., Sun, Y., Wolery, T.J., Bourcier, W., Tompson, A.F.B., Jones, E.D., Friedmann, S.J., Aines, R.D., 2010. Combining brine extraction, desalinantion, and residual-brine with $\mathrm{CO}_{2}$ storage in saline formations-implications for pressure management, capacity, and risk mitigation. Energy Procedia. www4.eventsinteractive.com/iea/viewpdf.esp?id $=270025 \&$ file=|\DCFILE01\EP11\%24\Eventwin\Poolloffice27\docs\pdflghgt10Final00414.pdf (accessed June 2011).

Celia, M.A., Bachu, S., 2003. Geological sequestration of $\mathrm{CO}_{2}$ : Is leakage unavoidable and acceptable? In: Gale, J.J., Kaya, Y. (Eds.). Proceedings of the 6th international conference on greenhouse gas control technologies, vol. I. Pergamon, Amsterdam, pp. 477-482.

CO2CRC Technologies Pty Ltd, 2008. A technical appraisal of the feasibility for $\mathrm{CO}_{2}$ sequestering operations for the Gorgon Gas Field development proposal—Phase III: technical report. www.dmp.wa.gov.au/documents/Executive_Summary_ from_Gorgon_DueDilligence_08_1028.pdf (accessed June 2013).

CO2CRC Technologies Pty Ltd, 2009. A technical appraisal of the feasibility for $\mathrm{CO}_{2}$ sequestering operations for the Gorgon gas field development proposal-Phase IV. Technical Report, August. www.dmp.wa.gov.au/documents/ExecSumIV.doc (accessed June 2013).

Colombo, L., Cursan, M., Dell'Orto, L., Piccinelli, C., Riboldi, L., 2010. Gorgon natural gas project. Norwegian University of Science and Technology, TPG 4140 Natural gas, November 2010.

Computer Modelling Group Ltd., 2014a. GEM user guide, compositional \& unconventional reservoir simulator, version 2014.

Computer Modelling Group Ltd., 2014b. WINPROP user guide, phase-behaviour \& fluid property program, version 2014.

Court, B., Celia, M.A., Nordbotten, J.M., Elliot, T.R., 2010. Active and integrated management of water resources throughout $\mathrm{CO}_{2}$ capture and sequestration operations. Energy Procedia. www4.eventsinteractive.com/iea/viewpdf.esp?id=270025\&file=11 DCFILE01\EP11\$IEventwin\Poolloffice27\docslpdflghgt10Final00103.pdf (accessed June 2011).

Curry, W.H., 1977. Teapot Dome—past, present, and future. American Association of Petroleum Geologists Bulletin 61(5).

Deutsch, C.V., Journel, A.G., 1998, GSLIB: Geostatistical Software Library and User's Guide, 2d ed., Oxford University press, New York, 1998, 350p.

Duncan, I.J., Nicot, J.-P., Choi, J.-W., 2009. Risk assessment for future $\mathrm{CO}_{2}$ sequestration projects based $\mathrm{CO}_{2}$ enhanced oil recovery in the U.S. Energy Procedia 1(1), 2037-2042. doi: 10.1016/j.egypro.2009.01.265.

Eke, P.E., Naylor, M., Haszeldine, S., Curtis, A., 2011. $\mathrm{CO}_{2}$ /brine surface dissolution and injection: $\mathrm{CO}_{2}$ storage enhancement. SPE Proj Fac \& Const 6(1), 41-53. SPE-124711-PA. doi: 10.2118/124711-PA.

Flett, M., Beacher, G., Brantjes, J., Burt, A., Dauth, C., Koelmeyer, F., Lawrence, R., Leigh, S., McKenna, J., Gurton, R., Robinson IV, W., Tankersley, T., 2008, Gorgon project-subsurface evaluation of carbon dioxide disposal under Barrow Island. In: SPE Asia Pacific Oil and Gas Conference, SPE 116372, Perth, Australia, October 20-22.

Flett, M., Brantjes, J., Gurton, R., McKenna, J., Tankersley, T., Trupp, M., 2009. Subsurface development of $\mathrm{CO}_{2}$ disposal for the Gorgon Project. Energy Procedia 1(1), February, 3031-3038.

Flett, M.A., Gurton, R.M., Taggart, I.J., 2005. Heterogeneous saline formations: Long-term benefits for geo-sequestration of greenhouse gases. Proceedings of the 7th International Conference on Greenhouse Gas Control Technologies (GHGT-7), September 5-9, Vancouver, BC, Canada, v. 01 I, 501-510.

Fleury, M., Gautier, S., Gland, N., Boulin, P., 2010. Petrophysical measurements for $\mathrm{CO}_{2}$ storage-Application to the Ketzin site. Society of Core Analysts SCA News SCA2010-06 22 (2). 
Forster, A., Norden, B., Zinck-Jorgensen, K., Frykman, P., Kulenkampff, J., Spangenberg, E., Friedmann, S.J., Stamp, V.W., 2006. Teapot Dome-characterization of a $\mathrm{CO}_{2}$-enhanced oil recovery and storage site in eastern Wyoming. Environmental Geosciences 13, 181-199.

Frykman, P., Zink-Jorgensen, K., Bech, N., Norden, B., Forster, A., Larsen, M., 2006. Site characterization of fluvial, incised-valley deposits. In: CO2SC Symposium, Lawrence Berkeley National Laboratory.

Gao, P., Sorensen, J., Braunberger, J., Doll, T., Smith, S., Gorecki, C., Hawthorne, S., Steadman E., and Harju, J., 2014. Updated regional technology implementation plan for Zama. Report, February 2014.

Gorecki, C.D., Liu, G., Bailey, T.P., Sorensen, J.A., Klapperich, R.J., Braunberger, J.R., Steadman, E.N., Harju, J.A., 2013. The role of static and dynamic modeling in the Fort Nelson CCS Project. Energy Procedia, 37, 3733-3741.

Henninges, J., Liebscher, A., Bannach, A., Brandt, W., Hurter, S., Köhler, S., Möller, F., 2011. CO2SINK Group, and two-phase fluid conditions with inverted density profile in observation wells at the $\mathrm{CO}_{2}$ storage site at Ketzin (Germany). Energy Procedia 4, 6085-6090.

Holloway, S., Chadwick, A., Lindeberg, E., Czernichowski-Lauriol, I., Arts, R. (Eds.), 2004. Sleipner best practice manual: Saline Aquifer $\mathrm{CO}_{2}$ Storage Project (SACS), 53 p.

Hosseini, S.A., Nicot, J.P., 2012. Scoping analysis of brine extraction/re-injection for enhanced $\mathrm{CO}_{2}$ storage. Greenhouse Gases: Science and Technology 2, 172-184.

IEA Greenhouse Gas R\&D Programme, 2009. Development of storage coefficients for carbon dioxide storage in deep saline formations. Technical report to U.S. Department of Energy and IEA Greenhouse Gas R\&D Programme. IEA Environmental Projects Ltd., 2009/12.

IEA Greenhouse Gas R\&D Programme, 2012. Extraction of formation waters from $\mathrm{CO}_{2}$ storage. 2012/12.

IEA Greenhouse Gas R\&D Programme, 2014. $\mathrm{CO}_{2}$ storage efficiency in deep saline formations, in press.

Kempka, T., Kuhn, M., Class, H., Frykman, P., Kopp, A., Nielsen, C.M., Probst, P., 2010. Modelling of $\mathrm{CO}_{2}$ arrival time at Ketzin-Part I. Elsevier International Journal of Greenhouse Gas Control 4, 1007-1015.

Klapperich, R.J., Cowan, R.M., Gorecki, C.D., Liu, G., Bremer, J.M., Holubnyak, Y.I., Kalenze, N.S., Kundsen, D.J., Saini, D., Botnen, L.S., LaBonte, J.L., Stepan, D.J., Steadman, E.N., Harju, J.A., Basva-Reddi, L., McNemar, A., 2013. IEAGHG investigation of extraction of formation water from $\mathrm{CO}_{2}$ storage. Energy Procedia, 37, 2479-2686.

Kopp, A., Bielinski, A., Ebigbo, A., Class, H., Helmig, R., 2006. Numerical investigation of temperature effects during the injection of carbon dioxide into brine aquifers, GHGT 8. www.co2sink.org/publications/GHGT8_IWS_UniStuttgart.pdf (accessed June 2011).

Kovscek, A.R., 2002. Screening criteria for $\mathrm{CO}_{2}$ storage in oil reservoirs. Petroleum Science and Technology 20(7-8), 841-866.

Kumar, A., Noh, M.H., Sepehrnoori, K., Pope, G.A., Bryant, S.L., Lake, L.W., 2005. Simulating $\mathrm{CO}_{2}$ storage in deep saline aquifers. In: Benson, S.M. (Ed.), Carbon Dioxide Capture for Storage in Deep Geologic Formations - Results from the $\mathrm{CO}_{2}$ Capture Project, v. 2: Geologic Storage of Carbon Dioxide with Monitoring and Verification. Elsevier, London, pp. 977-898.

Liu, G. (Ed.), 2012. Carbon dioxide geological storage: Monitoring technologies review, greenhouse gases-capturing, utilization and reduction. ISBN: 978-953-51-0192-5, InTech, www.intechopen.com/books/greenhouse-gases-capturing-utilization-andreduction/carbon-dioxide-geological-storage-monitoring-technologies-review (accessed June 2013).

Liu, G., 2010. Numerical modeling of near-serface $\mathrm{CO}_{2}$ migration with barometric pumping effects, Ph.D. dissertation, Civil and Environmental Engeneering, West Virginia University. 
Liu, G., Braunberger, J., Gorecki, C., Gao, P., Peck, W., Steadman, E., and Harju, J., 2014. Integrated modeling and simulation for $\mathrm{CO}_{2}$ EOR and $\mathrm{CO}_{2}$ storage in the Zama pinnacle reefs of Alberta Basin, Canada. 2014 SEG/SPE/AAPG/SPWLA/EAGE Summer Research Workshop, San Diego, California, August 3-6, 2014.

Liu, G., Saini, S., Gorecki, C., Bremer, J., Klapperich, R., 2013. Four-site case study of water extraction from $\mathrm{CO}_{2}$ storage reservoirs. Energy Procedia, 37, 4518-4528.

Liu, G., Smirnov, A., 2007. Modeling of carbon sequestration in coal-beds: A variable saturated simulation. Energy Conversion and Management 49(10), 2849-2858.

Liu, G., Smirnov, A., 2008. Carbon sequestration in coal-beds with structural deformation effects. Energy Conversion and Management 50(6), 1586-1594.

Martens, S., Liebscher, A., Möller, F., Würdemann, H., Schilling, F., Kühn, M., 2010. Ketzin Group progress report on the first European on-shore $\mathrm{CO}_{2}$ storage site at Ketzin (Germany)—second year of injection. Energy Procedia 4, 3246-3253.

Massachusetts Institute of Technology, 2011. Gorgon fact sheet: carbon dioxide capture and storage project, modified November 23, 2011. http://sequestration.mit.edu/tools/projects/gorgon.html (accessed November 2011).

Metz, B., Davidson, O., Coninck, H., Loos, M., Meyer, L., 2005. Special report on renewable energy sources. IPCC Special Report on Carbon Dioxide Capture and Storage, Cambridge University Press.

Milliken, M., 2007. Geothermal resources at Naval Petroleum Reserve 3 (NPR-3) Wyoming. In: Thirty-Second Workshop on Geothermal Reservoir Engineering Stanford University, Stanford, California, January 22-24, 2007. http://pete.stanford.edu/ERE/pdf/IGAstandard/SGW/2007/millike.pdf (accessed June 2013).

Norden, B., Förster, A., Vu-Hoang, D., Marcelis, F., Springer, N., Le Nir, I., 2010. Lithological and petrophysical core-log interpretation in $\mathrm{CO} 2 \mathrm{SINK}$, the European $\mathrm{CO}_{2}$ onshore research storage and verification project. SPE Res Eval \& Eng 13(2), $179-192$.

Prevedel, B., Wohlgemuth, L., Henninges, J., Krüger, K.C., Norden, A., Föster, A., 2008. The $\mathrm{CO}_{2}$ sink boreholes for geological $\mathrm{CO}_{2}$-storage testing. Scientific Drilling 6, 32-37.

Rocky Mountain Oilfield Testing Center, 2007. NPR-3 well data set. U.S. Department of Energy.

Rocky Mountain Oilfield Testing Center, 2011. Reservoir data-NPR-3/Teapot Dome. U.S. Department of Energy.

Saini, D., Gorecki, C.D., Knudsen, D.J., Sorensen, J.A., Steadman, E.N., 2013. A simulation study of simultaneous acid gas EOR and $\mathrm{CO}_{2}$ storage at Apache's Zama F Pool. Energy Procedia, 37, 3891-3900.

Schilling, F., Borm, G., Würdemann, H., Möller, F., Kühn, M., 2009. Status report on the first European on-shore $\mathrm{CO}_{2}$ storage site at Ketzin (Germany). Energy Procedia 1(1), 2029-2035.

Schlumberger, Petrel, 2012. Shared earth - critical insight.

Shaw, J.C., Bachu, S., 2002. Screening, evaluation and ranking of oil reserves suitable for $\mathrm{CO}_{2}$ flood EOR and carbon dioxide sequestration. Journal of Canadian Petroleum Technology 41(9), 51-61.

Trupp, M., 2011. personal communication, July 17.

White, C.M., Smith, D.H., Jones, K.L., Goodman, A.L., Jikich, S.A., LaCount, R.B., DuBose, S.B., Odemir, E., Morsi, B.I., Schroeder, K.T., 2005. Sequestration of carbon dioxide in coal with enhanced coalbed methane recovery - a review. Energy Fuels 19(3), 659-724. 
Wiese, B., Böhner, J., Enachescu, C., Würdemann, H., Zimmermann, G., 2010a. Hydraulic characterisation of the Stuttgart formation at the pilot test site for $\mathrm{CO}_{2}$ storage, Ketzin, Germany. International Journal of Greenhouse Gas Control 4(6), 960971.

Wiese, B., Nimtz, M., Klatt, M., Kühn, M., 2010b. Sensitivities of injection rates for single well $\mathrm{CO}_{2}$ injection into saline aquifers. Chemie der Erde - Geochemistry 70(3), 165-172.

Würdemann, H., Möller, F., Kühn, M., Heidug, W., Christensen, N., Borm, G., Schilling, F., 2010. The CO 2 SINK Group, $\mathrm{CO}_{2} \mathrm{SINK}$ - from site characterisation and risk assessment to monitoring and verification —one year of operational experience with the field laboratory for $\mathrm{CO}_{2}$ storage at Ketzin, Germany. International Journal of Greenhouse Gas Control 4(6), 938-951.

Zero Emission Resource Organisation, 2011. Salt Creek EOR, last modified July 19, 2011. www.zeroco2.no/projects/salt-creek-eor (accessed November 2011). 

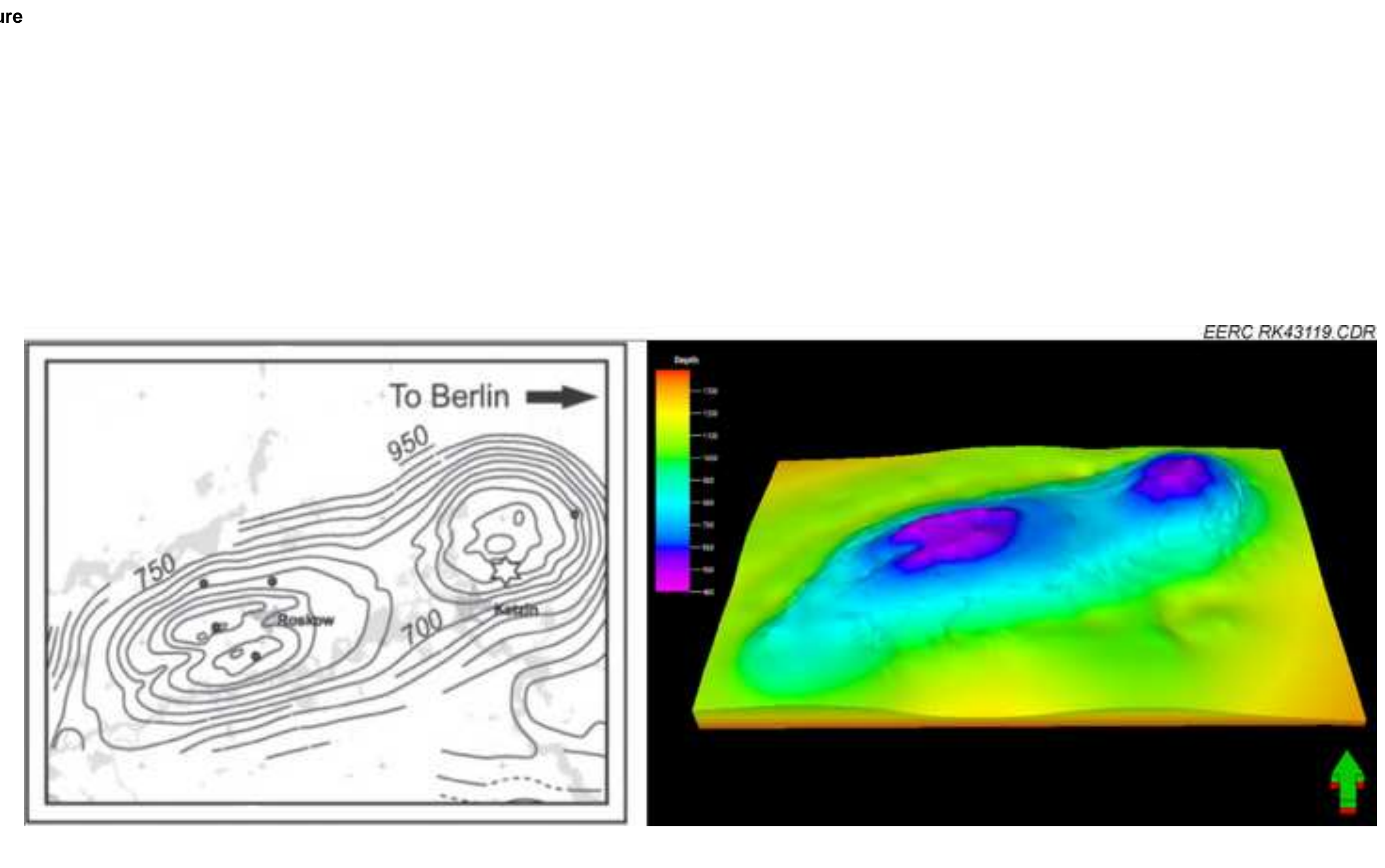

EERC RK43119.CDR

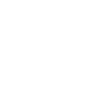

in \\ Page 30 of}
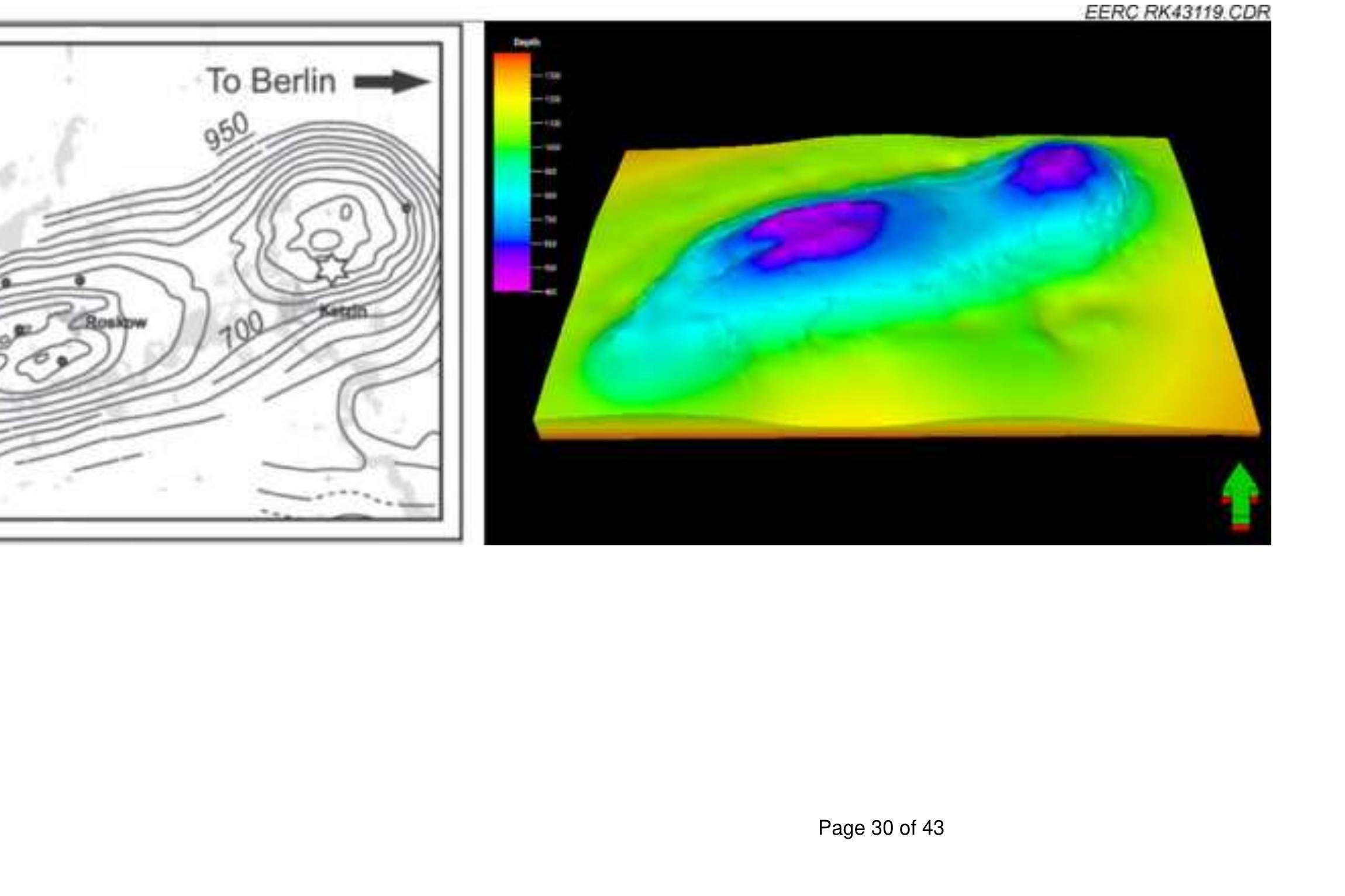
Ketzin $\mathrm{CO}_{2}$ Storage and Water Extraction

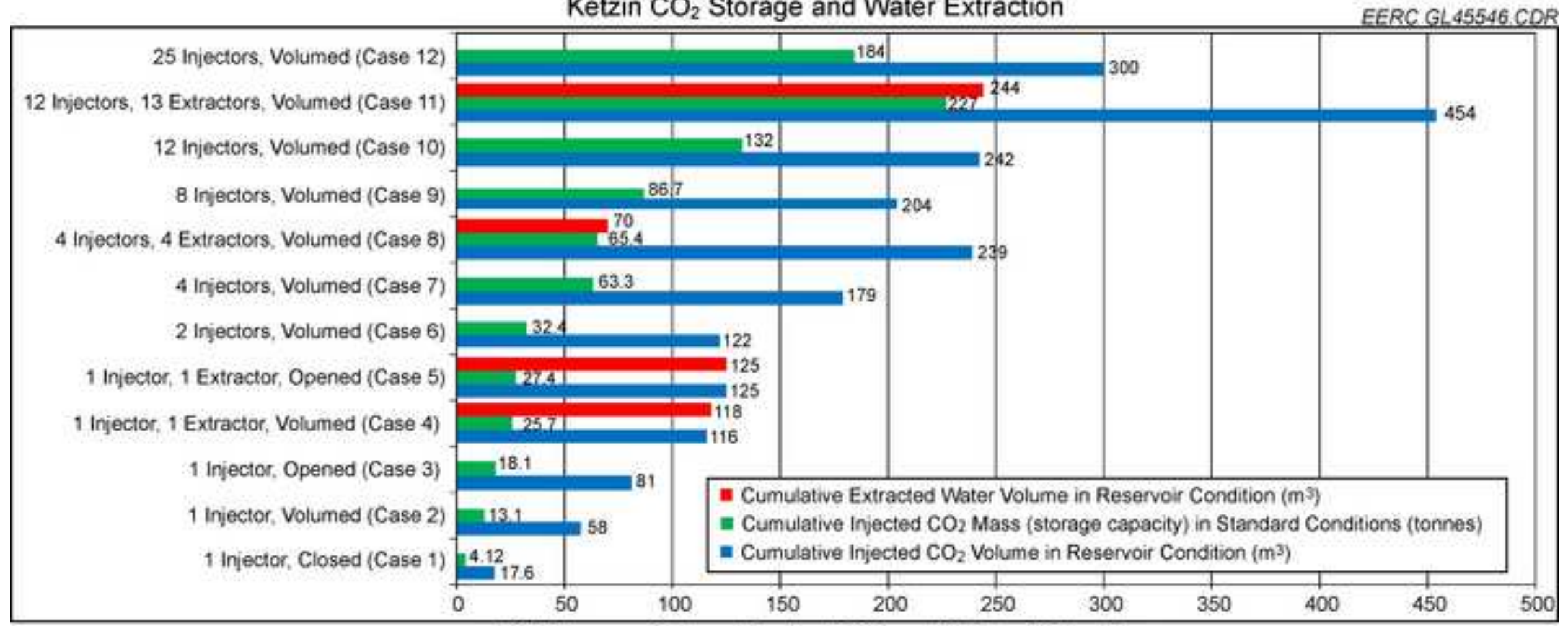

xE6 Volume of Mass Injected $\mathrm{CO}_{2}$ and Water Extraction 


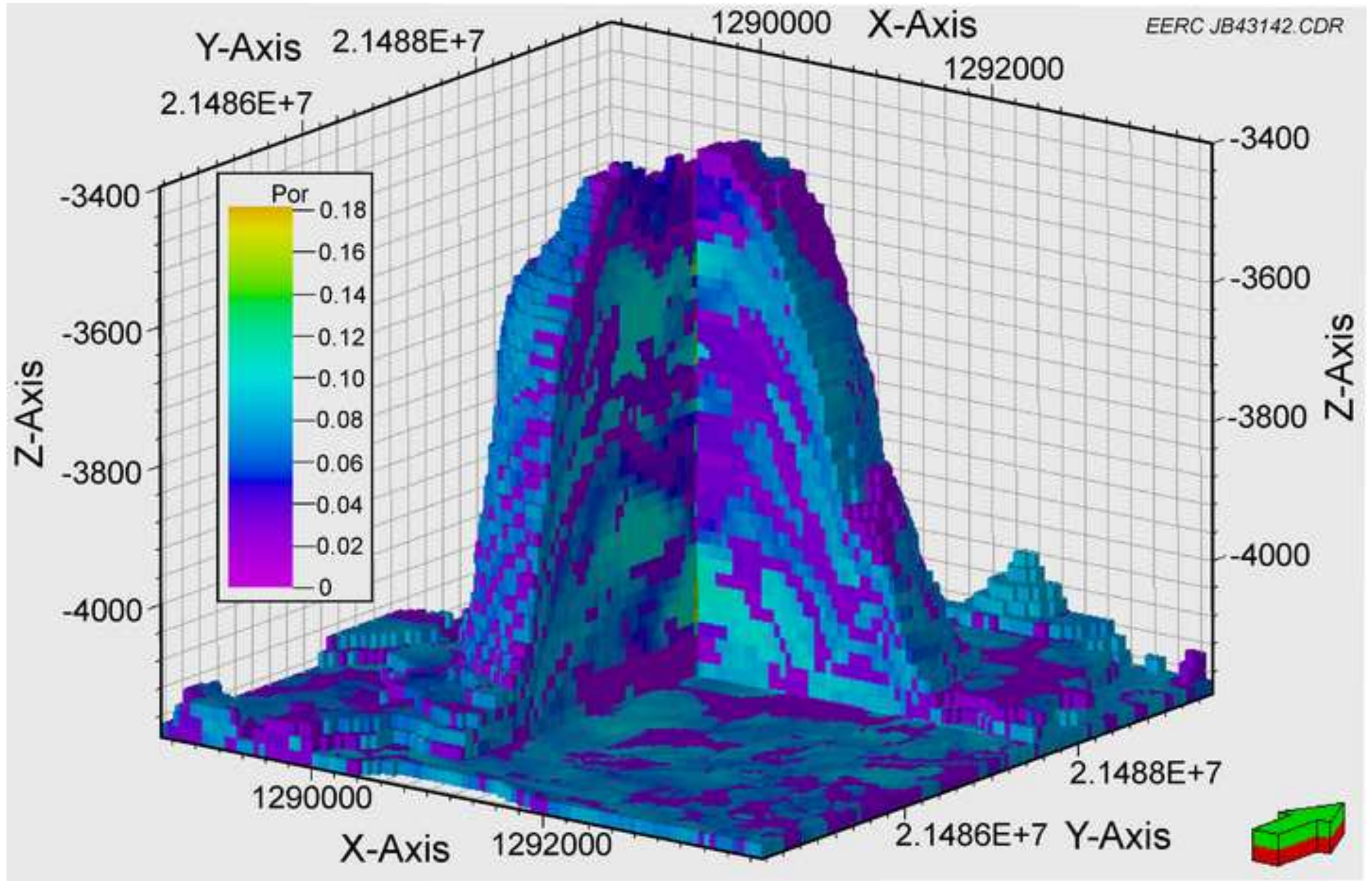


Zama $\mathrm{CO}_{2}$ Storage and Water Extraction

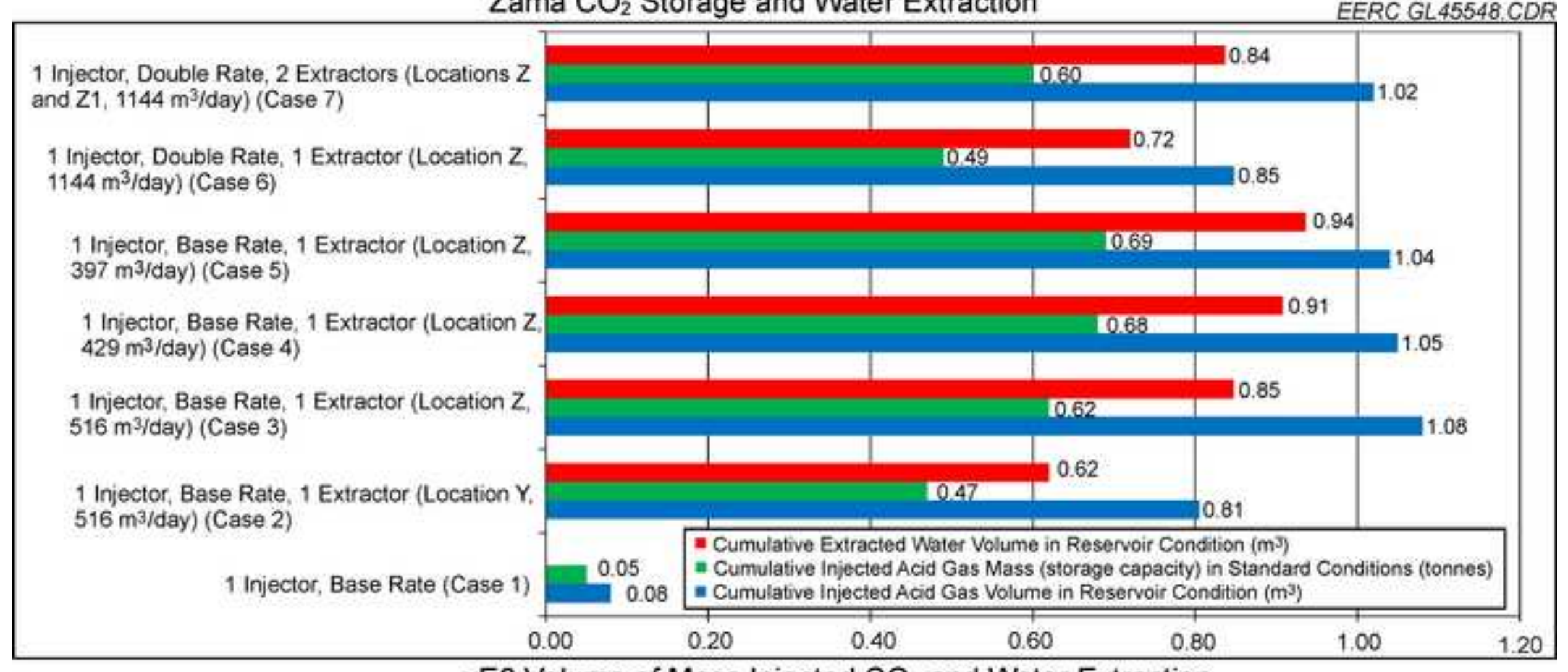

xE6 Volume of Mass Injected $\mathrm{CO}_{2}$ and Water Extraction 
Por.Erf.

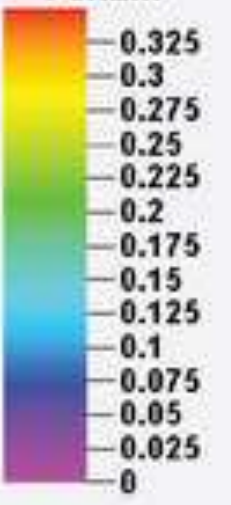

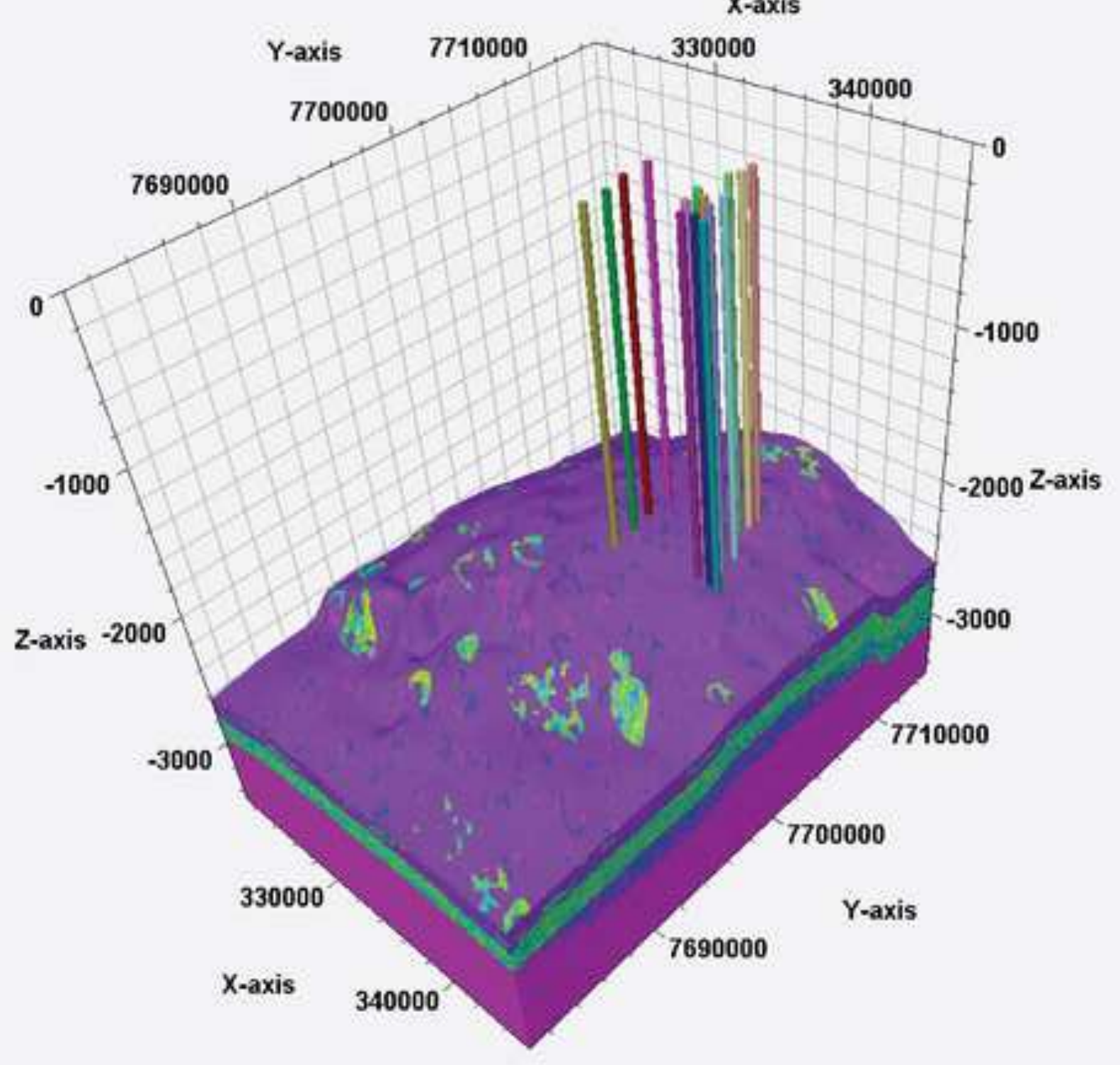


Gorgon $\mathrm{CO}_{2}$ Storage and Water Extraction

FERC GL 45551 CDR

8 Injectors, 4 Extractors, 25-yr, 7.5 Times Rate. Volumed (Case 7)

8 injectors, 25-yr, 7,5 Times Rate, Volumed (Case 6)

8 Injectors, 4 Extractors, 50-yr, Half Rate, Volumed (Case 5)

8 Injectors. 4 Extractors; 50-yr. Base Rate, Volumed (Case 4)

8 injectors, 50-yr, Base Rate, Volumed (Case 3)

8 Injectors, 4 Extractors, 25-yr, Base Rate, Volumed (Case 2)

8 Injectors, 25-yr, Base Rate, Volumed (Case 1)

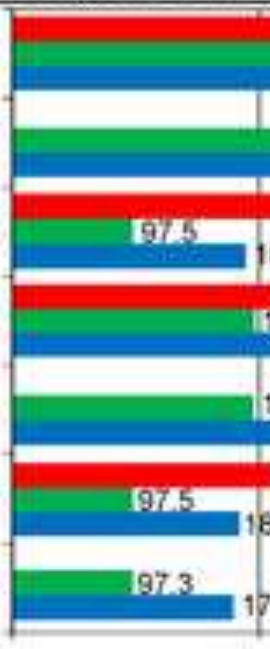

262

$1{ }_{637}$

637

1050

0

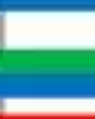

[551]

397

$396-397$

195

215

- Cumulative Extracted Water Volume in Reservoir Condition ( $\mathrm{m}^{3}$ )

= Cumulative injected $\mathrm{CO}_{2}$ Mass (storage capacity) in Standard Conditions (tonnes)

= Cumulative injected $\mathrm{CO}_{2}$ Volume in Reservoir Condition $\left(\mathrm{m}^{3}\right)$

$400 \quad 600$

800

1000

1200

XE6 Volume of Mass Injected $\mathrm{CO}_{2}$ and Water Extraction 
Teapot Dome $\mathrm{CO}_{2}$ Storage and Water Extraction

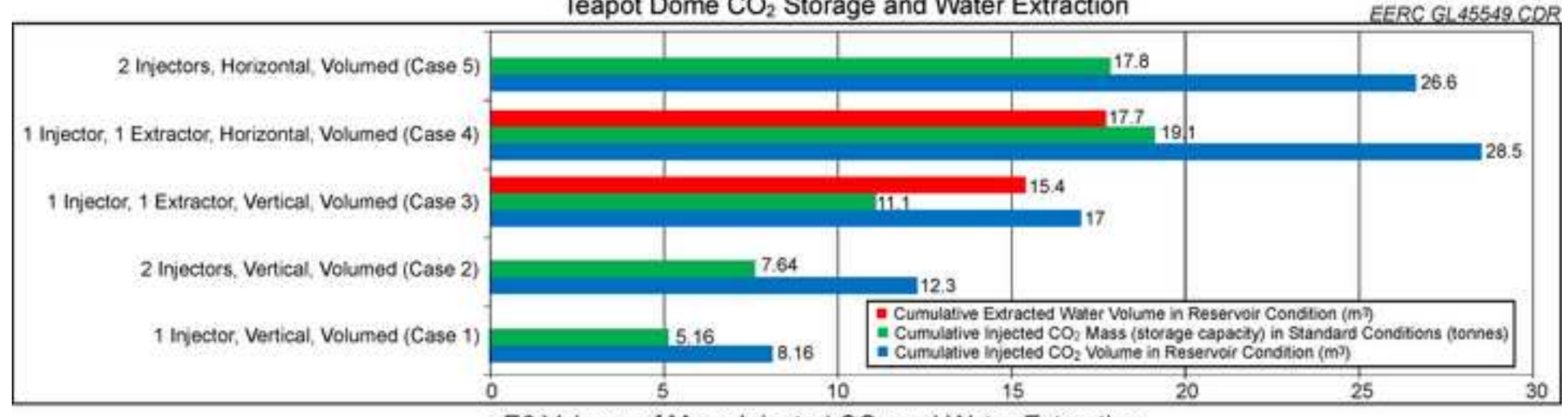

xE6 Volume of Mass Injected $\mathrm{CO}_{2}$ and Water Extraction 
EERC GL50508.AI

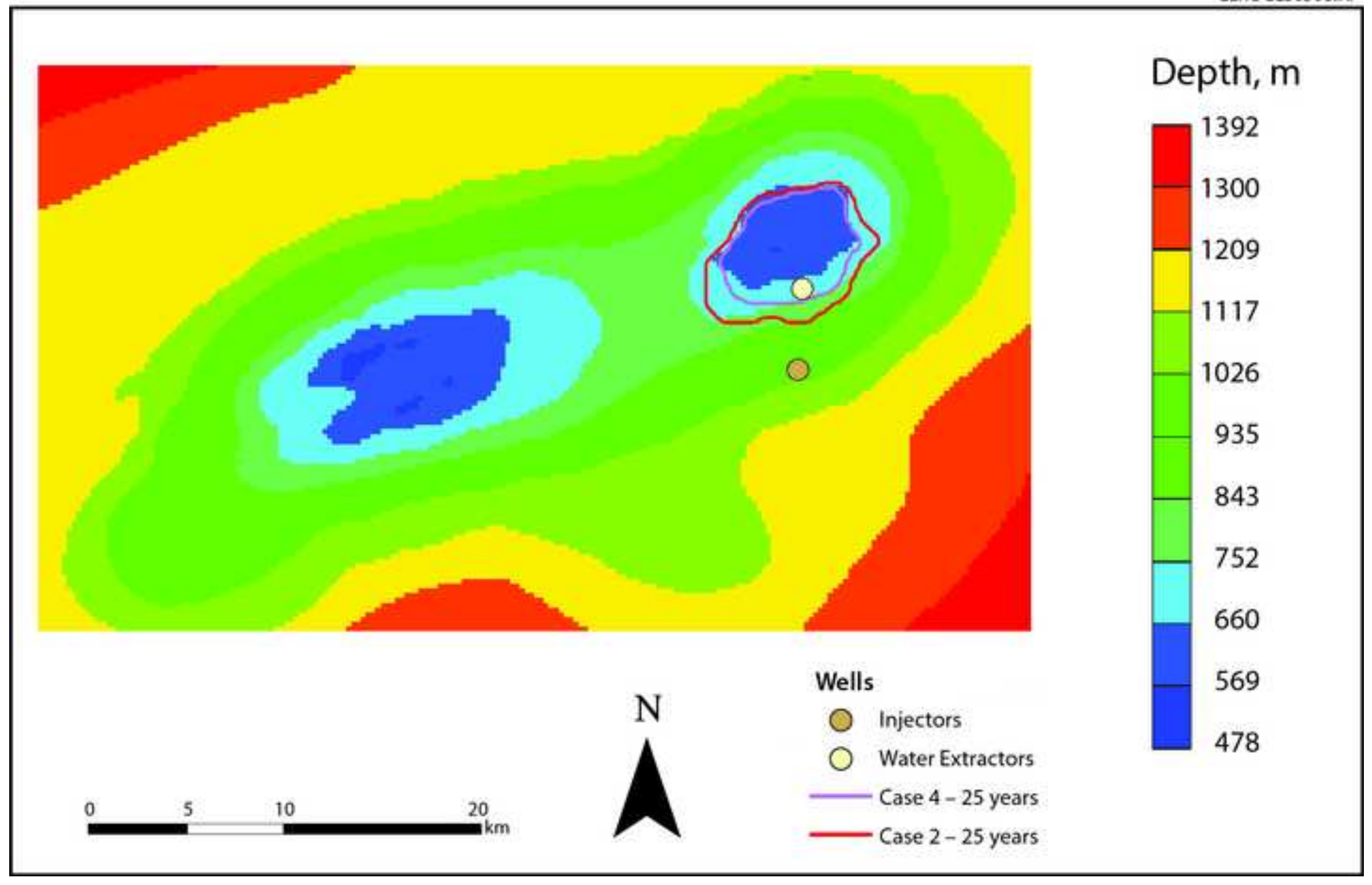

Page 37 of 43 


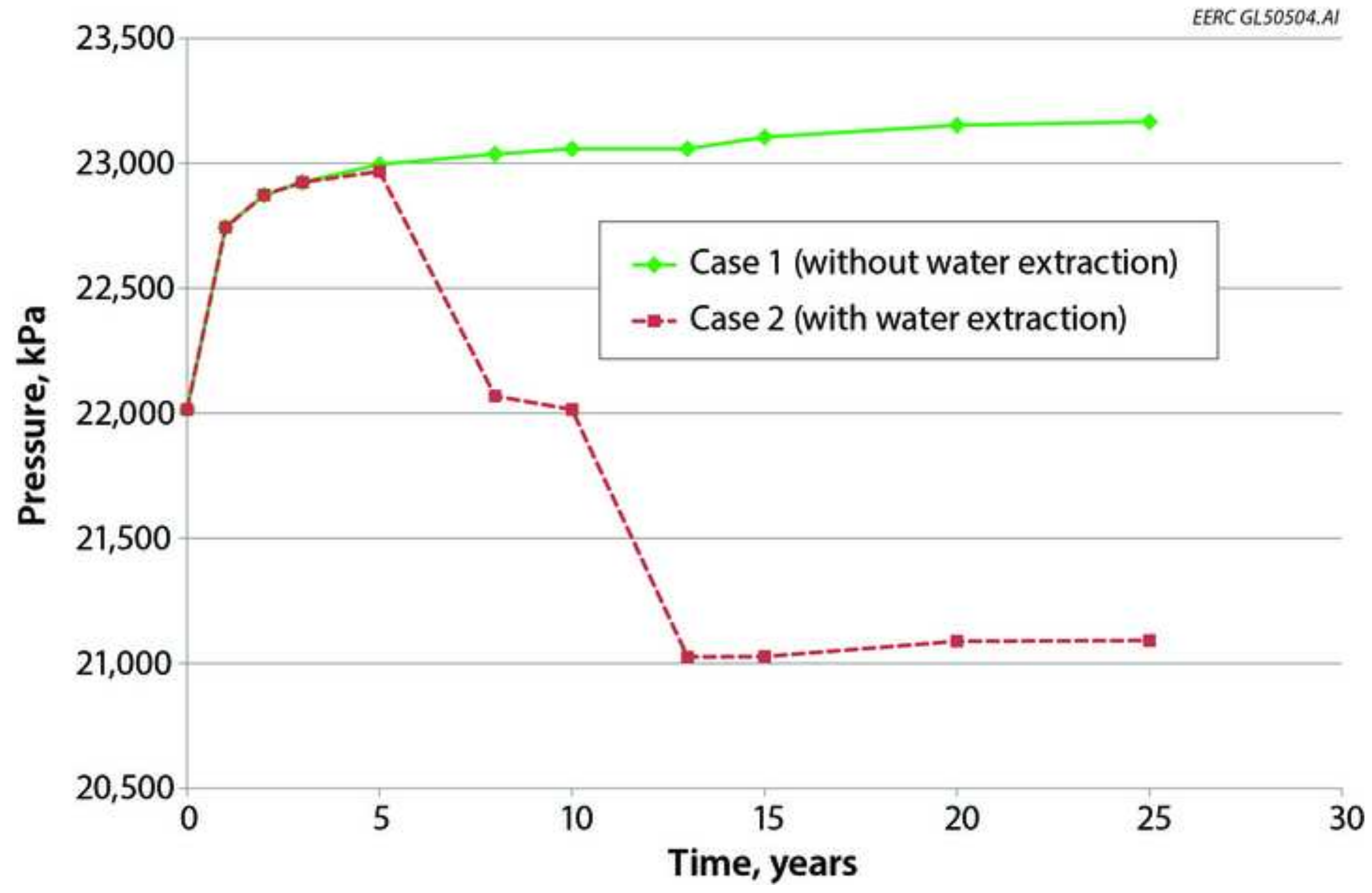




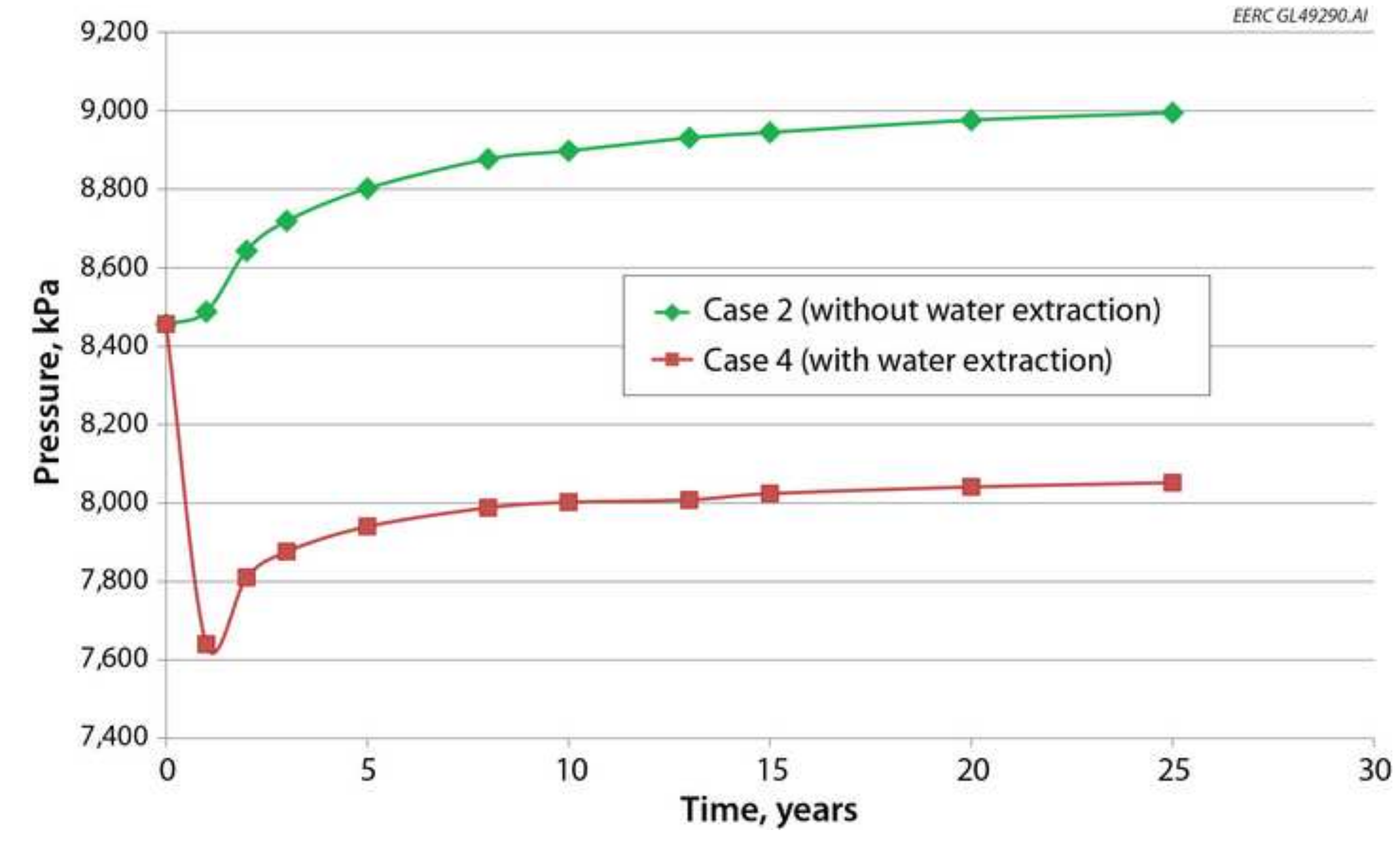

\section{Time, years}

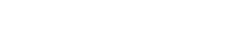


EERC GL49289.AI

\section{Depth, m}

\begin{tabular}{|l|l}
3150 \\
3040 \\
2930 \\
2820 \\
2710 \\
2600 \\
2490 \\
2380 \\
2270 \\
2160 \\
2050 \\
\hline
\end{tabular}
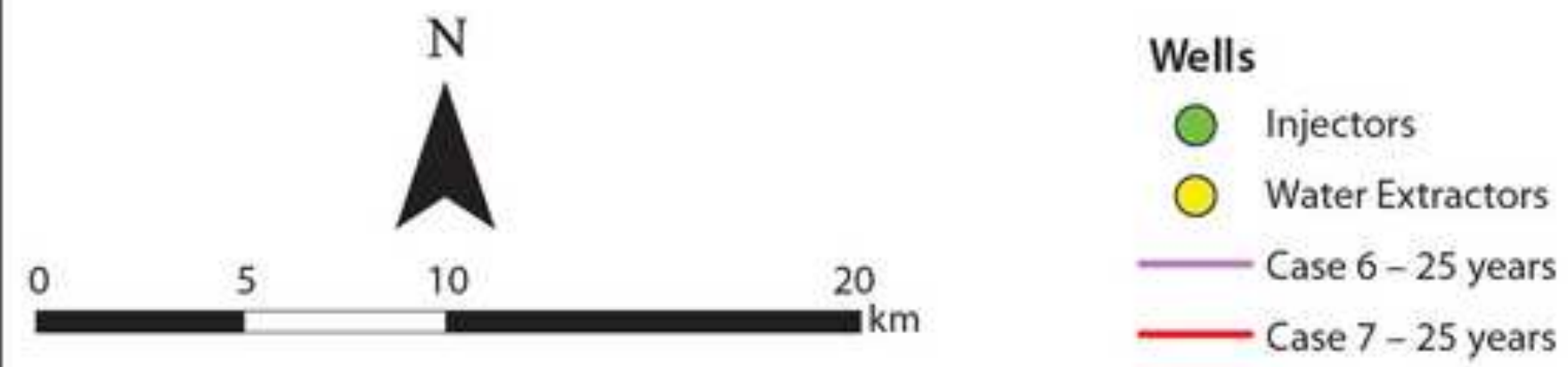
EERC GL.50505.AI

\section{Depth, $\mathrm{m}$}

\begin{tabular}{|l|l|}
3150 \\
3040 \\
2930 \\
2820 \\
2710 \\
2600 \\
2490 \\
2380 \\
2270 \\
2050
\end{tabular}


Por.Eff.

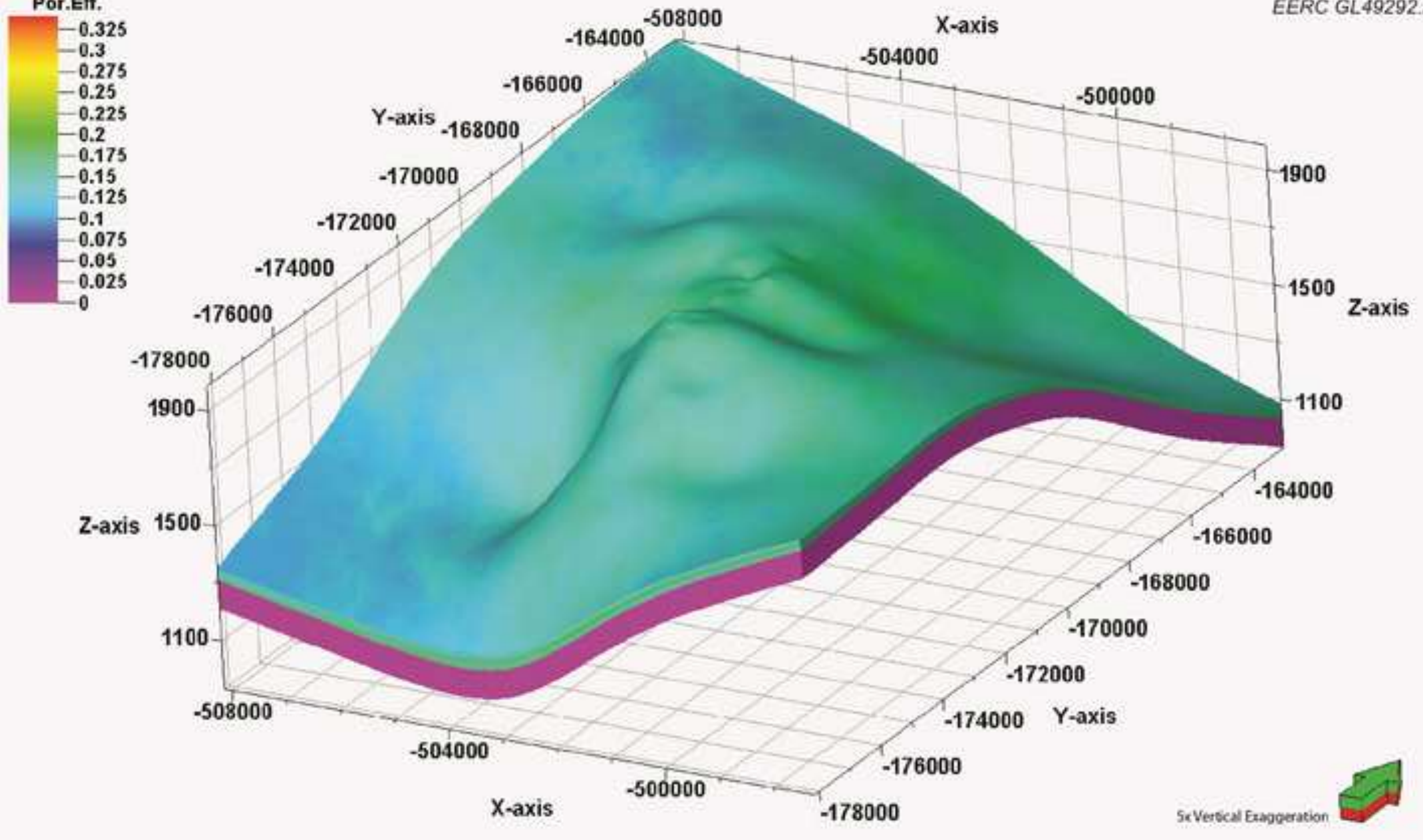



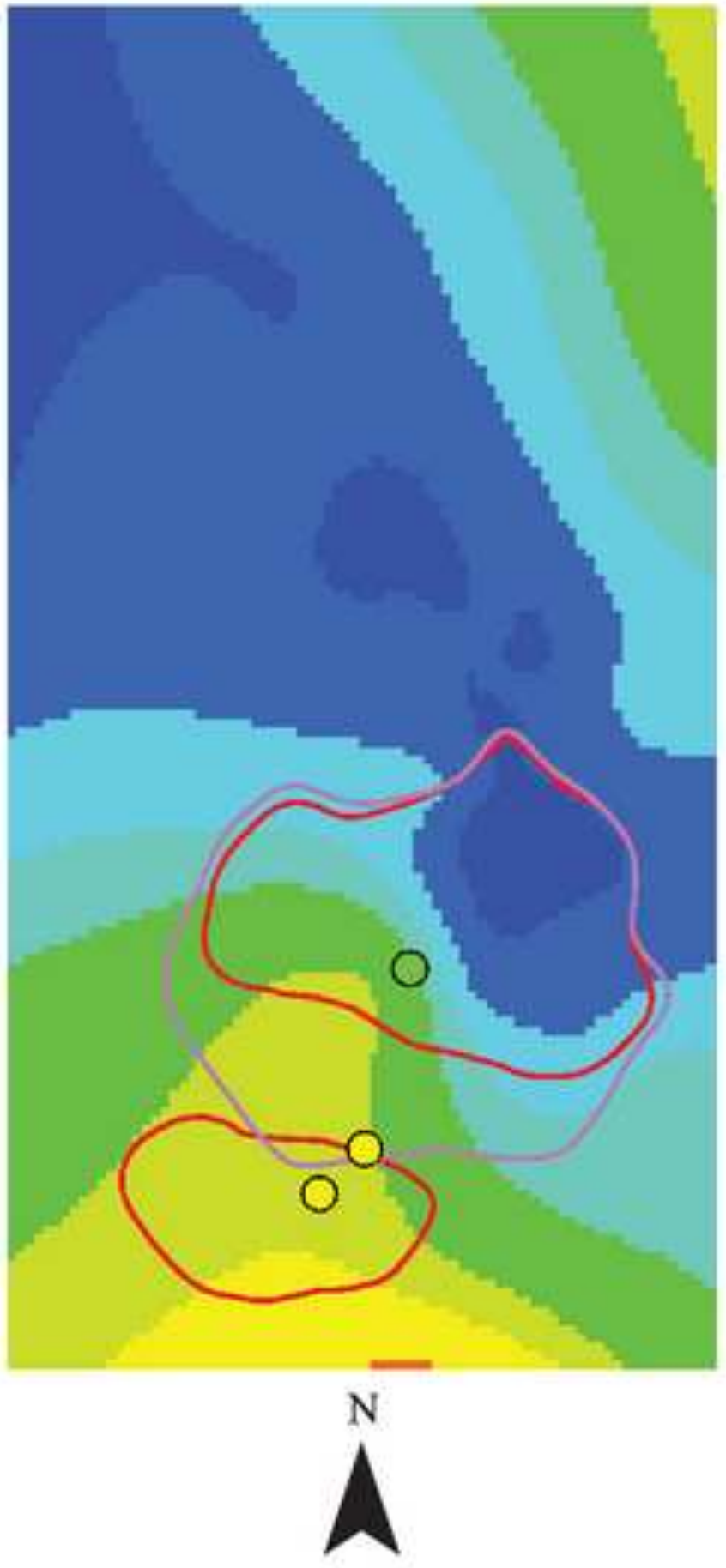

$\begin{array}{llll}0 & 1.25 & 2.5 & 5 \\ & & & \end{array}$
Depth, m

\begin{tabular}{|r}
2000 \\
1900 \\
\hline 1800 \\
1700 \\
1600 \\
1500 \\
\hline 1400 \\
1300 \\
1200 \\
1100 \\
1000
\end{tabular}

Wells

Injectors

Water Extractors

Case $4-25$ years

Case $5-25$ years 